\title{
Polska A, B i C? Volební geografie vybraných polských vojvodství
}

\author{
Poland A, B and C? Electoral Geography of Selected Voivodeships in Poland
}

\author{
MATĚJ POSPÍCHAL ${ }^{1}$
}

\begin{abstract}
The study focuses on spatial analysis of the general election results in Lower Silesia, Lodz. and Lesser Poland voivodeships in a period between 2001 and 2015. Primary subjects of the analysis are political parties Law and Justice, Civic Platform, Polish People's Party and Democratic Left Alliance, but particularly works also with the results of another parties (Self-Defence, League of Polish families, Modern). Standard electoral geography methodological methods, such as cartographic display of election results, correlation analysis and concentration of the election results measurement have been used on the local level and along with Polish and Czech literature review are included in the study. Main goal of the study was to find out if there are structural differences in terms of electoral support for the parties on both regional and voivodeship level. The analysis proved deeper context of the election results in the eastern regions along with a changing spatial structure of the Law and Justice support in the first decade of the 21st century and related deepening differences between voter bases of the Law and Justice and the Civic Platform- strongest parties in Poland. Findings of the analysis might be useful for upcoming research of the analysis of the electoral support in terms of regional differences.
\end{abstract}

Keywords: Electoral Geography; Spatial Analysis; Elections; Maps; Poland; Sejm; Voivodeships

\section{1. Úvod}

Zájem o polskou politiku se poslední dobou opět dostává do popředí zájmu české odborné i laické veřejnosti. Jednou z klasických politologických subdisciplín, kde se tento zájem může projevovat, je výzkum volební geografie a prostorového rozložení volební podpory polských politických stran. Základní územní rozdělení polského státu, od nějž se odvozuje rozdílné politické, ale i sociální a kulturní chování částí polské společnosti, je všeobecně známé a získalo už několik různých

1 Doktorand, Katedra politologie, Fakulta sociálních studií, Masarykova univerzita, Joštova 10, 602 00, Brno, Česká republika / Ph.D. candidate, Department of Political Science, Faculty of Social Studies, Masaryk University, Czech Republic. E-mail: 397656@mail.muni.cz. 
označení: západ vs. východ, Polsko A vs. Polsko B, modernisté vs. tradicionalisté (Šulc 2011: 24) a další.

Kořeny tohoto rozdělení spadají do období tzv. Trojího dělení Polska, které proběhlo v letech 1772-1795. Uzemí polsko-litevské Republiky obou národů bylo rozděleno mezi jeho tehdy mocnější sousedy: Ruské impérium postupně zabralo rozsáhlou východní část státu, Prusko získalo území na západě a Habsburské monarchii připadla zejména oblast Haliče (Davies 2003: 162). K obnovení Polska došlo až po první světové válce, nicméně v odlišných (a zmenšených) hranicích. Druhá světová válka a následné poválečné stanovení hranic Polska přinesla výrazný rozchod s historickým územním vývojem země, nebot' se celá země „posunula“ přibližně 250 kilometrů západním směrem. Mapa 1 zachycuje tuto odlišnou historickou př́slušnost jednotlivých oblastí.

\section{Mapa 1: Současné Polsko dle záborů platných do roku 1914 (1945)}

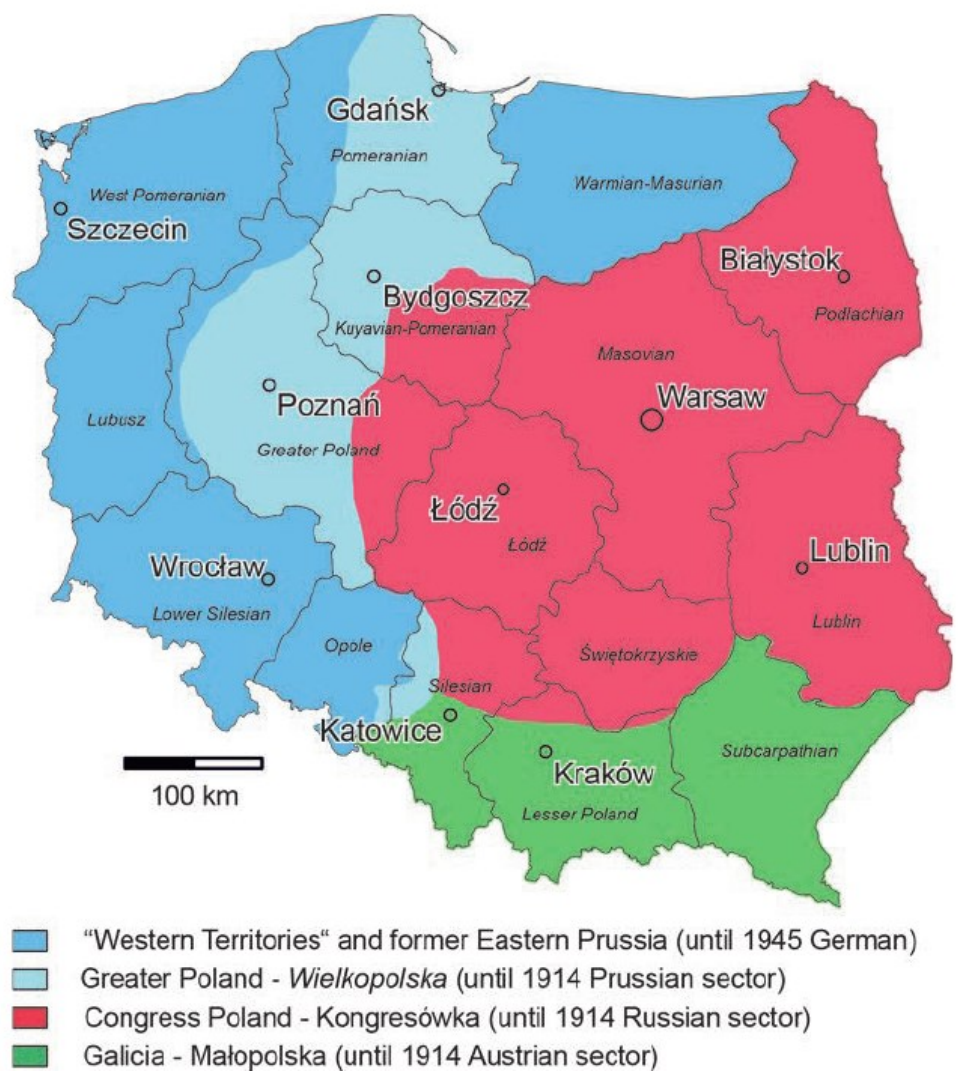

Zdroj: Zarycki 2015: 109. 
V období nesvobodné Polské lidové republiky pochopitelně nelze hovořit o politické soutěži, ve které by se mohlo projevit odlišné politické smýšlení občanů. Dohody, vzešlé z tzv. Kulatého stolu ovšem vedly ke „kontraktovým“ volbám v roce 1989 a plně svobodným v dalších letech. Důsledkem bylo vytvoření stranického systému, který se s různou dynamikou vyvijí dodnes. Od počátku tohoto tisíciletí lze hovořit o postupné stabilizaci stranického systému, od roku 2005 pak zejména o soupeření dvou stran, Občanské platformy (Platforma Obywatelska, PO) a Práva a spravedlnosti (Prawo i Sprawiedliwość, PiS). Tyto subjekty a jejich volební podpora vhodně ilustrují současné rozdělení polské společnosti. Volby, at' již parlamentní či ještě výrazněji prezidentské, ukazují na jednoznačnou linii zlomu volební podpory těchto stran a jejich reprezentantů, které se približně shodují s historickými hranicemi naznačenými výše. Kromě toho se pochopitelně projevují také další konfliktní linie (např. město vs. venkov) a vliv menších stran, jejichž podpora ovšem není natolik územně jednoznačná, jako je tomu v př́ípadě $\mathrm{PO}$ a PiS.

Tématem textu bude prostorové rozložení volební podpory v polských vojvodstvích, které prošly historicky odlišným vývojem. Kromě Dolnoslezského (bývalé německé oblasti) a Lodžského vojvodství (které dříve patřilo Rusku) bude do srovnání zařazeno také vojvodství Malopolské, které bývá z hlediska volebních výsledků povětšinou řazeno do východní části země, ve které dominuje Právo a spravedlnost. Historicky však jde o jinou část země, nebot' po tzv. Prvním dělení Polska v roce $1772^{2}$ patřila až do konce I. světové války Rakousku, resp. Rakousko-uherské monarchii. Z toho důvodu je lepší pojmout tuto oblast, tzv. západní Halič (kterou kromě Malopolska tvoři ještě sousední Podkarpatské vojvodství), jako samostatnou entitu. Výběr těchto tří vojvodství je postaven na jejich vzájemné kompatibilitě, a to především z hlediska socioekonomického. Právě vzhledem k faktu, že regiony tvoří (na polské poměry) kompaktní skupinu, není pozornost věnována směrem ke zkoumání vztahu těchto ukazatelů s výsledky politických subjektů, nebot' nejsou považovány za faktor, který by v tomto prípadě hrál určující roli - studie se bude soustředit na volební výsledky, jejich detailní analýzu a následnou interpretaci zjištění, která přinesla.

Současné vyšší územně správní celky (tj. vojvodstvî) existují v Polsku od roku 1999. Vzhledem $\mathrm{k}$ tomu, že prvních parlamentních voleb po jejich zř́zení v roce 2001 se již zúčastnily PO a PiS, představuje období 2001-2015 a patery volby, které se během této doby odehrály, dostatečně dlouhý časový úsek pro analýzu. Kromě dvou výše zmíněných stran bude zkoumána také volební podpora Polské strany lidové (Polskie Stronnictwo Ludowe, PSL) a Svazu demokratické levice

\footnotetext{
$2 \mathrm{~S}$ částečnou výjimkou Krakova a jeho blízkého okolí, které byly k Rakousku připojeny až v roce 1846 po zániku Svobodného města Krakova (Řezník 2002: 149). I předtím však byl tento útvar pod rakouským vlivem.
} 
(Sojusz Lewicy Demokratycznej, SLD ${ }^{3}$ ) (popř. volební koalice, kterých byla součástî), nebot' tyto dva subjekty představovaly stabilní součásti stranického systému. Z důvodů, které budou $\mathrm{v}$ textu dále zmíněny, je sekundární pozornost věnována také volebním výsledkům několika dalších stran, a to $\mathrm{v}$ případech, $k d y$ jejich analýza umožňuje lepší porozumění významným posunům u PiS a PO - jde konkrétně o Sebeobranu (Samoobrana Rzeczpospolitej Polskiej, S) a Ligu polských rodin (Liga Polskich Rodzin, LPR) v roce 2005, kdy tyto radikálnější subjekty naposledy podruhé a naposledy získaly zástupce v Sejmu a v následujících dvou letech měly poměrně významný vliv na polskou politiku, a konečně také stranu Moderní (Nowoczesna, M.), která v prozatím posledních volbách překonala pětiprocentní hranici.

V článku budou využity metodologické nástroje volební geografie, jako je např. Území stabilní volební podpory, korelační analýza, variační a Giniho koeficient. Úrovní, na které budou tyto postupy využity, jsou tzv. gminy, nejnižší územně správní jednotky v polské samosprávě.

Výzkumné cíle této studie lze rozdělit na dvě části. První se týká rozdílů mezi vybranými vojvodstvími. Samotné volební výsledky stran jsou pochopitelně známé, jejich detailnější analýza však pomůže zjistit, zda existují rozdíly mezi vojvodstvími, které, jak již bylo zmíněno, odlišují faktory spíše historického charakteru. $\mathrm{V}$ jiných ohledech jsou podobné a ani jejich geografická vzdálenost není na polské poměry př́liš velká. Studie tedy bude hledat odpověd' (mimo jiné) na otázky: Byl vývoj podpory hlavních polských stran ve vojvodstvích podobný? Existuje souvislost $\mathrm{v}$ rozložení jejich elektorátů? A jak se mění v čase?

Druhá část cílů se týká jednotlivých, výše zmíněných stran. Pomocí zvolených metod bude možné učinit konstatování o jejich voličské základně v delším časovém období. Díky tomu bude možno zjistit, zda mají strany podobně koncentrovanou podporu $v$ různých částech země, $z d a$ je rozložení jejich elektorátu stabilní nejen v čase a prostoru, ale i v různých typech voleb (sněmovní, evropské a první kolo prezidentských). Řečeno otázkou - Byla postupná konsolidace stranického systému doprovázena konsolidací struktury volební podpory stran? A je tento vývoj regionálně rozdílný či obdobný?

Skladba textu této studie je následující: Nejprve bude představen současný stav výzkumu volební geografie v polském a českém prostředí. Dále je prostor věnován představení metodologických nástrojů využitých při analýze výsledků, jakož i podrobnějšímu vysvětlení výběru zkoumaných celků. $\mathrm{Na}$ to navazuje nejdůležitější část textu - nejprve jsou shrnuty volební výsledky zkoumaných subjektů $\mathrm{v}$ regionech, následně je zkoumán vztah volební podpory subjektů a poté bude pozornost upřena na analýzu volební podpory samotných stran. Dílčí

\footnotetext{
3 Až na výjimky bude $\mathrm{v}$ práci používáno označení SLD, a to i v případě, kdy budou popisovány situace, kdy se jednalo o volební koalici. Její ostatní komponenty totiž prakticky v žádném př́padě nepředstavovaly významnou složku společné kandidátní listiny.
} 
poznatky a určité zamyšlení nad hlavními zjištěními plynoucími ze studie budou poté shrnuty v závěru.

\section{Volební geografie Polska v tamní a české literatuře}

Prostorové rozložení volební podpory politických stran (a kandidátů) je pochopitelně v polském odborném prostředí reflektováno a na toto téma zde vzniklo již množství studií, kromě mateřského jazyka autorů jsou velmi často publikovány $\mathrm{v}$ angličtině. Historickému pohledu na Polsko a jeho politiku se věnují např̀. rozsáhlé práce Marka Kotera (Barwiński 2015). Mariusz Kowalski na přelomu tisíciletí analyzoval z volebně-geografického pohledu období 1989-1998 (Kowalski 2000) a rovněž také období meziválečné či volby v roce 1957 (Kowalski 2014, 2015).

Velice známé jsou především výzkumy Tomasze Zaryckého. Tento sociolog se věnoval také širšímu politickému areálu střední a východní Evropy (mj. i ČR), kde se snažil analyzovat vliv historických, geografických a dalších okolností na volební výsledky (Zarycki 1999). Některé jeho práce jsou však zaměřeny př́mo na Polsko. Již v roce 1997 vydal rozsáhlý text zaměřený na analýzu volebních výsledků parlamentních a prezidentských voleb od roku 1989. I zde je historický kontext velmi př́tomný, autor zde také rozděluje „německá“ území současného Polska na bývalý pruský zábor ${ }^{4}$ a na regiony, které Polsko získalo na úkor Německa po druhé světové válce. Pozornost také věnuje specifickým oblastem Polska, mj. Kašubsku či Podhalsku (Zarycki 1997). Zarycki se tématu polské volební geografie věnuje i v současnosti (Zarycki 2015).

Roli historických hranic uvnitř Polska v rámci výzkumu volební geografie reflektují i další autoři. Marek Barwiński v jejich kontextu analyzoval volební výsledky druhého kola prezidentských voleb 1995 a 2005, jakož i referenda o vstupu do Evropské unie v roce 2003 (Barwiński 2006).

Z dalších autorů lze jmenovat také Jarosława Jańczaka, který zasazuje rozdíly ve volebním chování Poláků v různých částech země do kontextu tzv. phantom borders ${ }^{5}$. Práce je kromě své aktuálnosti zajímavá také zaměřením na lokální úroveň dvou vojvodství (Velkopolského a Pomořského), které jsou protnuty hranicemi mezi Polskem A a B (Jańczak 2015).

V českém odborném prostř̌edí existuje řada výzkumů věnovaných jednotlivým aspektům polské politiky (např. Kubát 2005, 2006, Kopeček 2004, Koubek 2016 a mnohé dalšî), volební geografie Polska není v České republice v centru zájmu, byt' je možno nalézt několik textů, které se jí věnují. Hraje

${ }^{4}$ Z bývalých „pruských“ oblastí ovšem žádné vojvodství není vhodné pro zařazení do analýzy, mj. z důvodu nejednoznačné územní př́slušnosti (viz Mapa 3), ale také nekompatibilních socioekonomických statistik.

${ }^{5}$ Podrobněji k tomuto termínu a jeho užití prri výzkumu střední a východní Evropy viz Löwis (2015) 
podstatnou roli $\mathrm{v}$ práci výše zmíněného Jiř́ho Koubka, která se ovšem týká především voleb 2007 a menší míre předchozího politického měření sil v letech 2005 a 2001 (Koubek 2007). Určitý prostor je jí věnován také v práci Petra Sokola, která se věnuje volební geografii v postkomunistických zemích střední a východní Evropy (Sokol 2014). Za ucelený a rozsáhlý text zabývající se tímto tématem lze považovat diplomovou práci Jana Šulce, která zkoumá volební geografii v Polsku po roce 1989. Autor zde shrnuje výsledky voleb hlavy státu a členů dolní komory do roku 2010 a aplikuje na ně některé volebněgeografické postupy (např. sousedský efekt). Kromě toho věnuje významnou pozornost proměnám stranického systému nebo chování národnostních menšin Stejně jako polští autoři i Šulc potvrzuje významný vliv územních změn Polska, př́slušnosti částí jeho současného území $\mathrm{k}$ různě fungujícím státním celkům a s tím spojeným důsledkům na volební chování polských voličů (Šulc 2011).

Jeho text se však zabývá celým územím Polska (byt' se nevyhýbá ani popisu některých regionálních odlišností a specifik). Tento text poskytne důkladnější analýzu konkrétních územních celků v kratším časovém období, a to za pomoci většího množství kvantitativních nástrojů.

\section{Použité výzkumné nástroje a data}

Přestože postupy této studie svým charakterem nijak nevybočují z těch, které jsou v českém prostředí používány běžně, jejich krátké představení je jistě vhodné.

Metody je možno rozdělit do několika skupin. První z nich je měření prostorové variability volebních výsledků, které ukáže, jak moc jsou hlasy pro daný subjekt rozprostřeny na zkoumaném prostoru. Zde budou využity dva způsoby, variační a tzv. Giniho koeficient. První z nich, variační koeficient, se počítá pomocí standardních matematických funkcí dostupných např. v softwaru excelového typu. Minimální hodnota koeficientu je nula, která by značila zcela rovnoměrně rozložení podpory na zkoumaném území. Maximum stanoveno není, obvykle však zjištěné hodnoty nepřekračují číslo jedna. Tyto větší hodnoty značí vysoké rozdíly mezi jednotkami. Jelikož horní hranice chybí, je lepší hodnoty interpretovat na základě vzájemného srovnání výsledků, nikoli samu o sobě.

Variační koeficient však počítá s procentuálními zisky subjekti̊, a tudíž nebere v potaz rozdíly mezi velikostmi obcí (Kabeláčová 2014: 22). I z tohoto důvodu je vhodné tento výpočet doplnit Giniho koeficientem, který se běžně používá mj. při určování př́ijmové či důchodové nerovnosti. Jeho výpočet umožňuje zachytit velikostní rozdíly zkoumaných jednotek. Interpretace jeho hodnot je podobná, jako u variačního koeficientu, pouze hodnota 1, která značí absolutní nevyrovnanost výsledků, je jeho maximem. Samotný koeficient byl po nezbytné úpravě dat (podrobněji viz Voda 2015: 64) vygenerován pomocí online statistického softwaru Wessa.net. 
Dále můžeme u volebních výsledků měřit jejich souvislost s jinými daty, např̀. socioekonomickými údaji, nebo výsledky jiných stran či stejné strany v jiných volebních arénách. Souvislost se měří zjištěním tzv. korelačního koeficientu, který lze získat např. použitím statistického softwaru SPSS. Těchto koeficientů existuje více, zde bude použit Pearsonův korelační koeficient, který patří mezi nejčastěji využívané. Koeficient může nabývat hodnot od 1 do -1 , přičemž krajní hodnoty značí dokonalou souvislost (1), popr. nesouvislost (-1) zkoumaných jevů.

Zde bude koeficient použit na získání míry souvislosti mezi volebními výsledky stran ve volbách do dolní komory a jejich zisky hlasů ve volbách do Evropského parlamentu a prvního kola prezidentských voleb, do kterých (až na jednu výjimku u SLD) vždy vyslaly své zástupce. Tabulka 1 popisuje časové určení jednotlivých voleb.

Tabulka 1: Volby v Polsku zařazené do korelační analýzy v letech 2001-2015

\begin{tabular}{|c|c|c|c|c|c|c|c|c|c|}
\hline Typ voleb & \multicolumn{7}{|c|}{ Měsíc a rok konání } \\
\hline Parlamentní volby & $9 / 01$ & & $9 / 05$ & $10 / 07$ & & & $10 / 11$ & & $10 / 15$ \\
\hline Volby do EP & & $6 / 04$ & & & $6 / 09$ & & & $5 / 14$ & \\
\hline Prezidentské volby & & & $10 / 05$ & & & $6 / 10$ & & & $5 / 15$ \\
\hline
\end{tabular}

Zdroj: Vlastní tabulka

V několika př́padech bude využita také regresní analýza, přesněji řečeno její lineární podoba. Ta se používá pro změření vztahu mezi závislou proměnnou a jednou či více nezávislými proměnnými (Pink et al. 2012: 12). Zde půjde v obou př́padech, jejichž výběr bude vysvětlen později, o analýzu vztahu volebních výsledků stran. Klíčovými údaji jsou zde hodnoty koeficientů B a Beta, které popisují sílu vztahu proměnných. Pokud jsou kladné, značí zvýšení hodnoty závislé proměnné při současném růstu nezávislé proměnné (proměnných), záporné hodnoty značí opačný efekt. Zmíněny budou také hodnoty konstanty (hodnoty závislé proměnné při nulové hodnoty nezávislých) a indexu determinace, které ukazují míru variability závislé proměnné, které lze vysvětlit proměnnými nezávislými (Hendl 2009: 281).

Logickou součástí textů, které se věnují volební geografii a prostorovému rozložení volební podpory stran, je také kartografické zobrazení volebních výsledků. Jelikož jde $\mathrm{v}$ tomto př́padě o delší časový úsek zahrnující více voleb, bude nejvhodnější použít koncept území stabilní volební podpory od Petra Jehličky a Lud'ka Sýkory, který byl vytvořen již na počátku devadesátých let a umožňuje identifikovat prostor s kontinuální vysokou podporou jednotlivých subjektů (Jehlička a Sýkora 1991). Výpočet ÚSVP vyžaduje data o volebním výsledku subjektu jak $\mathrm{v}$ absolutních (hlasech), tak relativních (procentech)

${ }^{6}$ Jako měsíc konání je uveden ten, ve kterém proběhlo první kolo voleb. V roce 2010 bylo druhé kolo až v červenci. 
hodnotách a je následující: výsledky strany v (tomto př́padě) obcích jsou seřazeny dle procentuálních zisků od nejvyšších po nejnižších. V takto seřazeném datovém souboru je poté nutno vybrat tolik území, dokud jeho hodnota $\mathrm{v}$ součtu nepřesáhne $50 \%$ všech nasbíraných hlasů strany (ve vojvodstvî). Pouze ty obce, které do této skupiny patří ve všech zkoumaných volbách, je možné zařadit do ÚSVP (Voda 2015: 65).

Velmi podobným způsobem lze zkoumat také oblasti, ve kterých daný politický subjekt stabilně dosahuje nízkých volebních zisků. Zde se v průběhu let vyskytlo několik různých označení takových území, a rovněž také odlišné způsoby jejich stanovení. V této práci bude používán termín Území stabilní volební nepodpory a do něj budou řazeny gminy, ve kterých strana nezískala vyšší nebo stejnou procentuální podporu jako $\mathrm{v}$ celém vojvodství ve všech pěti volbách do dolní komory. Toto ÚSVN bude zobrazeno ve stejné mapě, jako ÚSVP, a barevně od něj odlišeno. Mapy v této práci byly vytvořeny v programu QGIS, což je software na tvorbu, analýzu a vizualizaci geoprostorových informací (QGIS 2017). Mapové podklady byly získány z Centrálního registru geografických a kartografických dokumentů (CODGIK 2017) a jednotlivá vojvodství vytvořena autorem textu filtrací gmin spadajících do zvolených regionů z těchto dat. Do takto získaných vrstev byla následně zanesena zjištěná data ohledně USVP a USVN a z nich byly vytvořeny mapy.

Stěžejní pro tuto práci bylo získání kompletních volebních výsledků, což bylo možné z oficiálních internetových stránek polské volební komise www.pkw.gow a jejich mutací pro jednotlivé volby. Ve většině př́ípadů bylo možno získat data v kompletní podobě a jednom datovém souboru, ze kterého bylo nutné pouze filtrování výsledků pro zkoumané subjekty a vojvodství, resp. gminy v něm ležící. Pouze v př́padě voleb do Sejmu v roce 2001 takovýto způsob získání dat nebyl možný a volební výsledky byly přepsány manuálně autorem.

\section{Výběr zkoumaných územních celků}

Ještě před samotnou analýzou volební podpory je vhodné trochu šíreji vysvětlit výběr výše zmíněných územních celků. Ty vznikly na základě reformy polské územní samosprávy, která proběhla v roce 1998. Složitě hledané kompromisy mezi koalicí, opozicí, prezidentem a jinými zájmovými skupinami nakonec daly vzniknout šestnácti vojvodstvím (viz Mapa 2), výrazně se od sebe lišícími velikostí, počtem obyvatel, původem názvů a dalšími parametry (více Chwalba 2009: 61-63 a Kubát 2005: 85-86). Od počátku roku 1999, kdy vojvodství oficiálně vznikla, doznaly pouze drobných změn v řádu jednotek gmin, které byly z některých VÚSC odebrány a připojeny $\mathrm{k}$ jiným, popř. změnily svůj název. Polskou samosprávu lze v tomto ohledu prozatím považovat za stabilní. 
Mapa 2: Vojvodství Polska od 1. 1. 1999

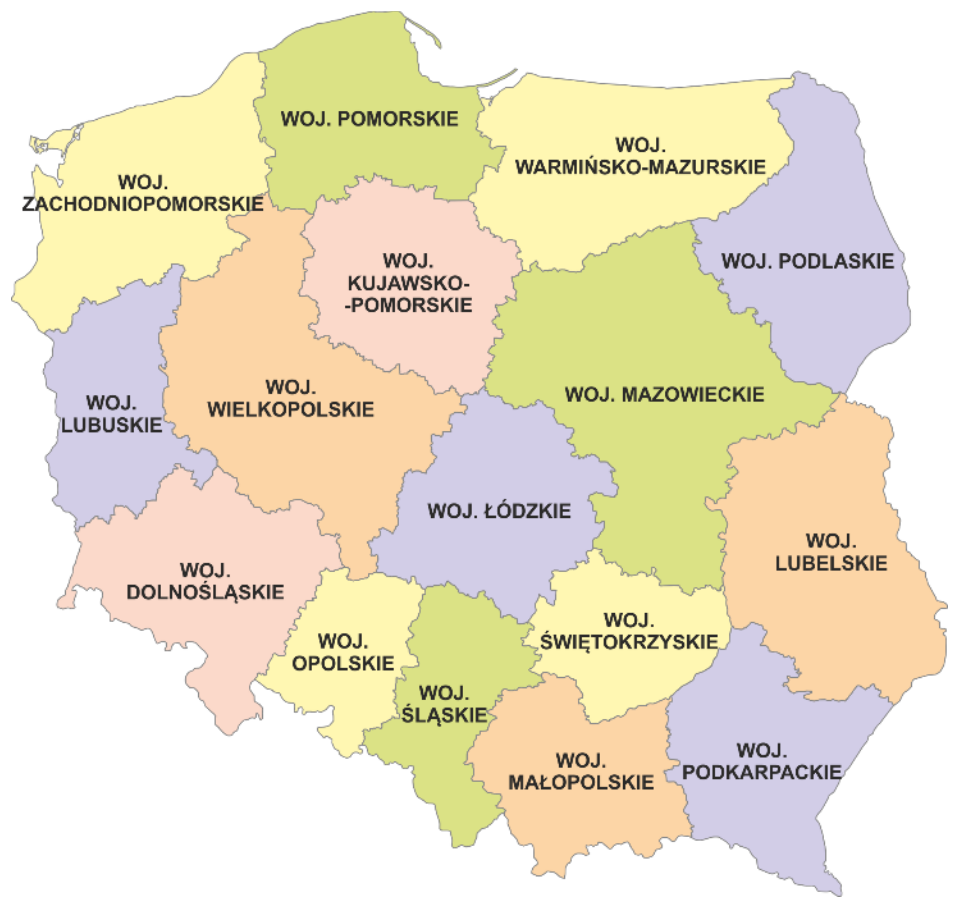

Zdroj: Główny Urząd Statystyczny 2017a.

Způsobů, jak vybrat jednotky vhodné ke vzájemnému srovnání, je pochopitelně více. Dolnoslezské, Lodžské a Malopolské vojvodství však vykazují podobnosti v základních socioekonomických aspektech, a proto byly zvoleny do analýzy (viz Mapa 3). Všechna tři tato vojvodství mají podobný počet obyvatel i gmin. Jejich hlavní města (Wrocław, Lodž a Krakov) se také velikostí oproti celku zásadně neliší. Podobná je také ekonomická síla regionů (byt' prošla nestejně rychlým vývojem) či míra nezaměstnanosti (viz Tabulka 2). 
Tabulka 2: Vybrané statistiky zkoumaných vojvodství Polska ${ }^{7}$

\begin{tabular}{|c|c|c|c|c|c|c|c|c|}
\hline Vojvodství & $\begin{array}{c}\text { Rozloha } \\
\text { (2015, } \\
\text { v tis. } \\
\text { km²) }^{2}\end{array}$ & $\begin{array}{l}\text { Počet } \\
\text { gmin } \\
\left(2015^{8}\right)\end{array}$ & 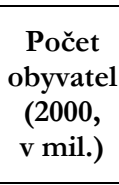 & $\begin{array}{c}\text { Počet } \\
\text { obyvatel } \\
\text { (2015, } \\
\text { v mil.) }\end{array}$ & $\begin{array}{c}\text { Nezam. } \\
(2004, \\
\text { v \%) }\end{array}$ & $\begin{array}{c}\text { Nezam. } \\
(2015, \\
\text { v \%) }\end{array}$ & $\begin{array}{c}\text { HDP/ } \\
\text { obyva- } \\
\text { tel } \\
(2001, \\
\text { zl) }\end{array}$ & $\begin{array}{c}\text { HDP / } \\
\text { obyva- } \\
\text { tel } \\
(2015, \\
\text { zl) }\end{array}$ \\
\hline Dolnoslezské & 19946 & 169 & 2,91 & 2,90 & 22,4 & 8,5 & 20617 & 50031 \\
\hline Lodžské & 18218 & 177 & 2,63 & 2,49 & 19,5 & 10,3 & 18238 & 41839 \\
\hline Malopolské & 15182 & 182 & 3,22 & 3,37 & 15,0 & 8,3 & 17880 & 39834 \\
\hline
\end{tabular}

Zdroj: Vlastní tabulka autora dle Główny Urząd Statystyczny 2015: 3, 2017b, 2017c, 2017d, 2017e, Komisja Standaryzacji Nazw Geograficznych 2015.

\section{Mapa 3: Vojvodství vybraná $\mathrm{k}$ analýze v rámci administrativního rozdělení Polska}

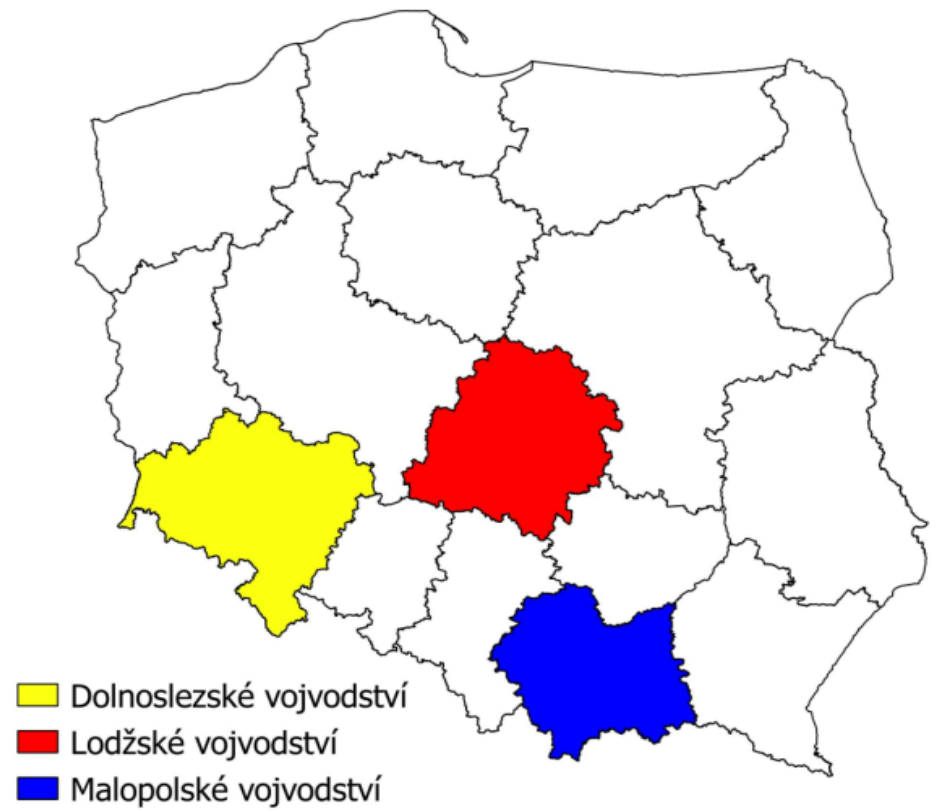

Zdroj: Vlastní mapa

${ }^{7}$ Data k rozloze a počtu obyvatel vojvodství jsou uvedena $\mathrm{k}$ 31. 12. daného roku, u počtu gmin je uveden stav k 1. 1., u nezaměstnanosti a HDP na obyvatele nejsou rozhodná data na internetovém portálu polského statistického úradu uvedena.

${ }^{8}$ Počet gmin zůstal po celé sledované období stejný, pouze v r. 2002 bylo v Malopolsku o jednu méně. 


\section{Výsledky voleb ve zkoumaném období}

Jak již bylo řečeno, v období 2001-2015 se v Polsku konaly volby do dolní komory celkem pětkrát, konkrétně v letech 2001, 2005, 2007 (předčasné), 2011 a 2015. Ačkoli zkoumané strany působily v Sejmu po celou dobu (SLD vypadl až po posledních volbách), jejich pozice a význam ve stranickém systému se za danou dobu s výjimkou PSL poměrně radikálně proměnil (viz Graf 1 ). SLD na počátku tisíciletí dokázala jednoznačně zvítězit, od té doby se však jedná o menší subjekt. Naopak Právo a spravedlnost a Občanská platforma se staly hlavními póly stranického systému. Zádné další strany (Liga polských rodin, Sebeobrana, Palikotovo hnutí, Kukiz'15, Modernî) ve zkoumaném období nepřekročily pětiprocentní hranici nutnou pro zisk poslaneckých mandátů více než dvakrát po sobě, byt' $\mathrm{v}$ prípadě posledních dvou je tato možnost ještě otevřená, nebot' poprvé kandidovaly až v posledních volbách v roce 2015.

Graf 1: Výsledky zkoumaných stran ve volbách do Sejmu v letech 2001-2015

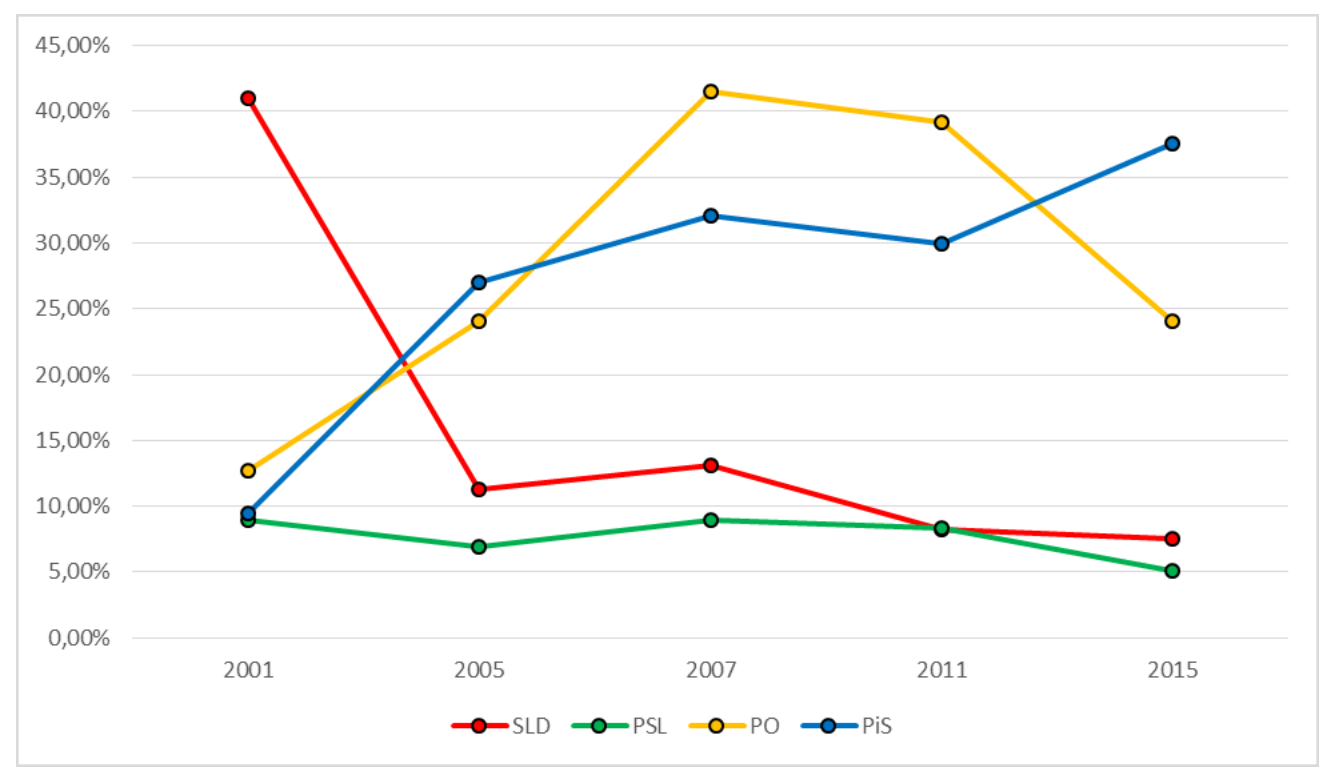

Zdroj: Vlastní graf autora dle NSD 2017, PKW 2015.

Vojvodství vybraná k analýze $\mathrm{v}$ této době do značné míry kopírovala celostátní trendy, byt' s některými odlišnostmi. Dolnoslezské vojvodství, které sousedí s Českou republikou a Německem, se postupem let stalo jednoznačnou volební baštou Občanské platformy a zůstalo jí až do posledních voleb. Vzrůst podpory Práva a spravedlnosti ovšem zapříčinil změnu v pořadí stran (viz Graf 2). 
Graf 2: Výsledky zkoumaných stran v Dolnoslezském vojvodství ve volbách do Sejmu v letech 2001-2015

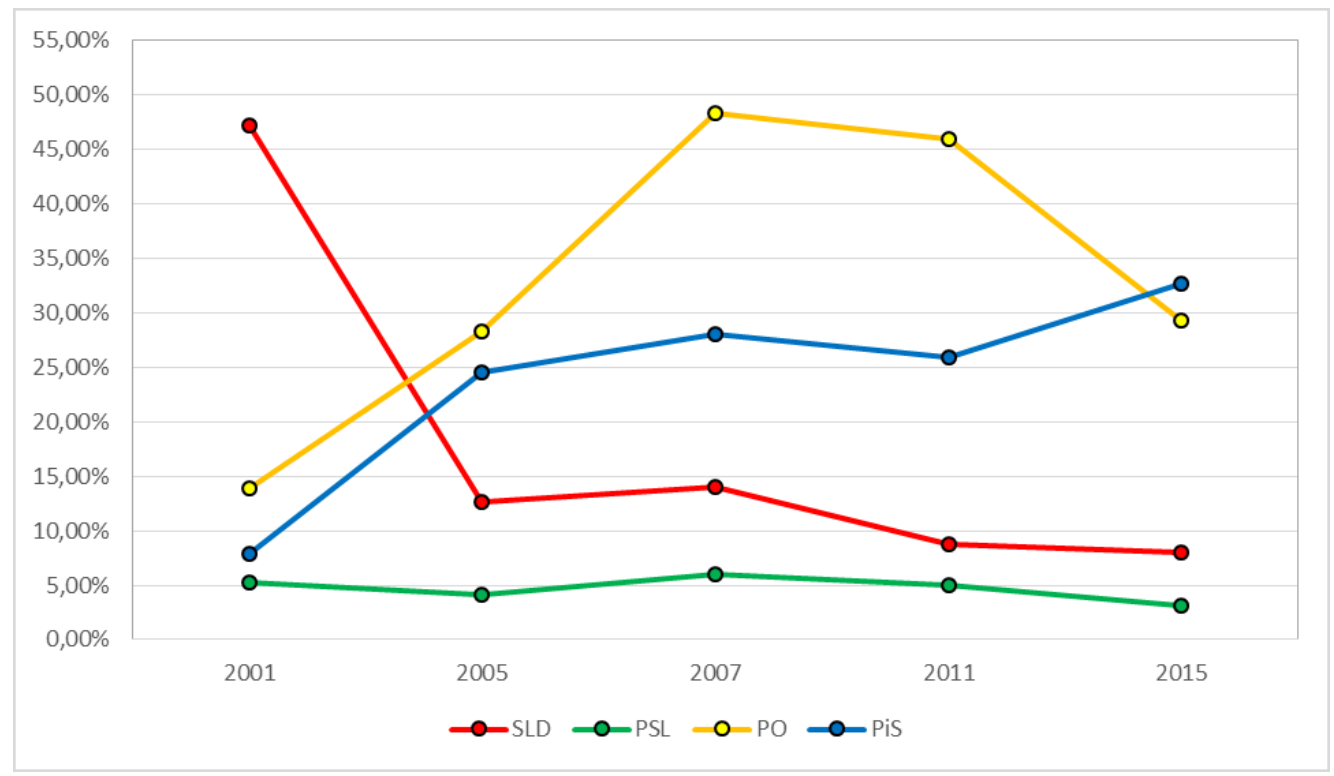

Zdroj: Vlastní graf autora dle NSD 2017, PKW 2015.

Graf 3 zachycuje lodžský region, který naopak nebyl jednoznačně zaslíben ani jedné ze stran. Po vítězství SLD v roce 2001 se v prvenství střídaly PO a PiS, přičemž mezi výsledky nebyl příliš velký rozdíl. Jednoznačné vítězství Práva a spravedlnosti v roce 2015 však tuto situaci změnilo, nad svým hlavním soupeřem triumfovalo s více než desetiprocentním náskokem. Zbývající dvě strany získaly výrazně menší podporu.

Právo a spravedlnost $\mathrm{v}$ posledních volbách potvrdilo svoji dlouhodobou převahu v Malopolsku, když získalo téměř polovinu hlasů voličů. PO, PSL a SLD (resp. Sjednocená levice) si zde vedla hưře než celostátně (viz Graf 4). Zejména $\mathrm{v}$ př́padě levicové koalice byl (tradičně) slabý výsledek $\mathrm{v}$ tomto regionu jednou z př́čin, že nepokořila osmiprocentní hranici, která je v polském volebním systému nutná pro přidělení mandátů $v$ př́padě předvolebních koalic, a není tedy v současnosti v Sejmu zastoupena. 
Graf 3: Výsledky zkoumaných stran v Lodžském vojvodství ve volbách do Sejmu v letech 2001-2015

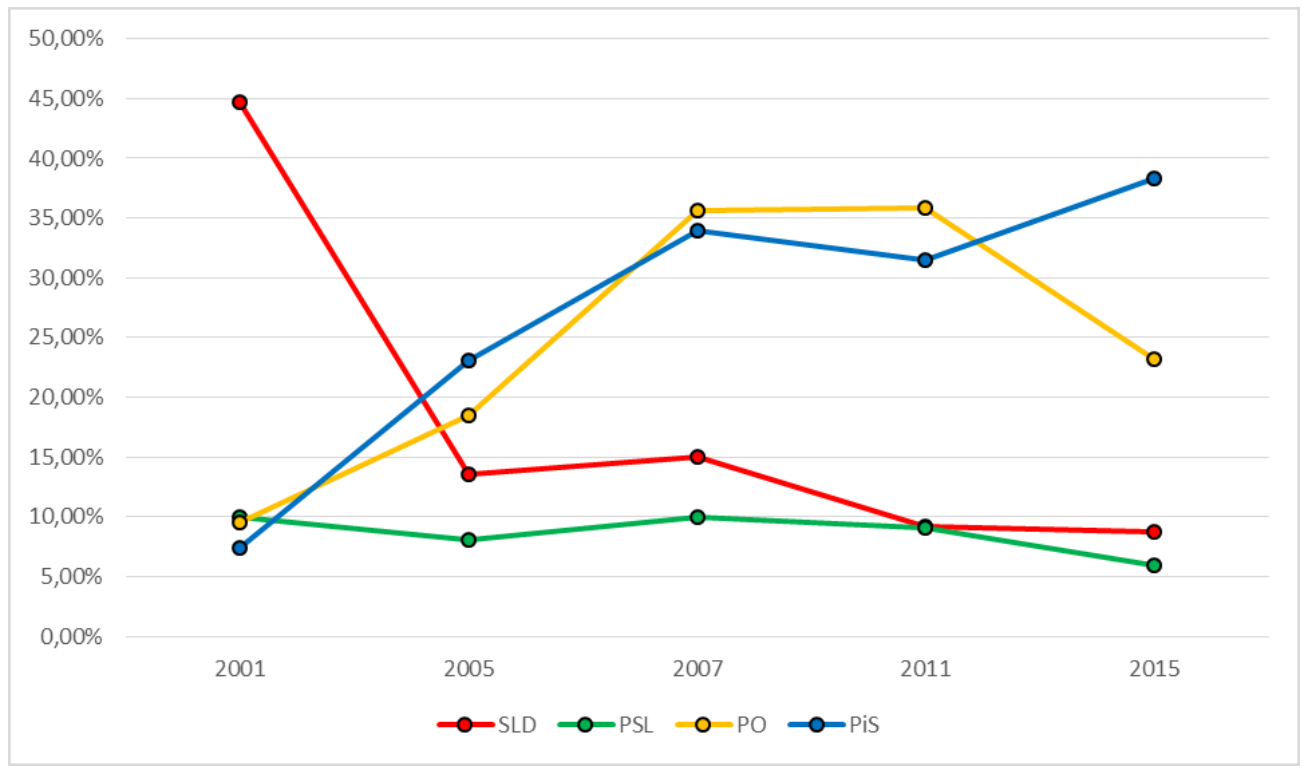

Zdroj: Vlastní graf autora dle NSD 2017, PKW 2015.

Graf 4: Výsledky zkoumaných stran $\mathbf{v}$ Malopolském vojvodství ve volbách do Sejmu v letech 2001-2015

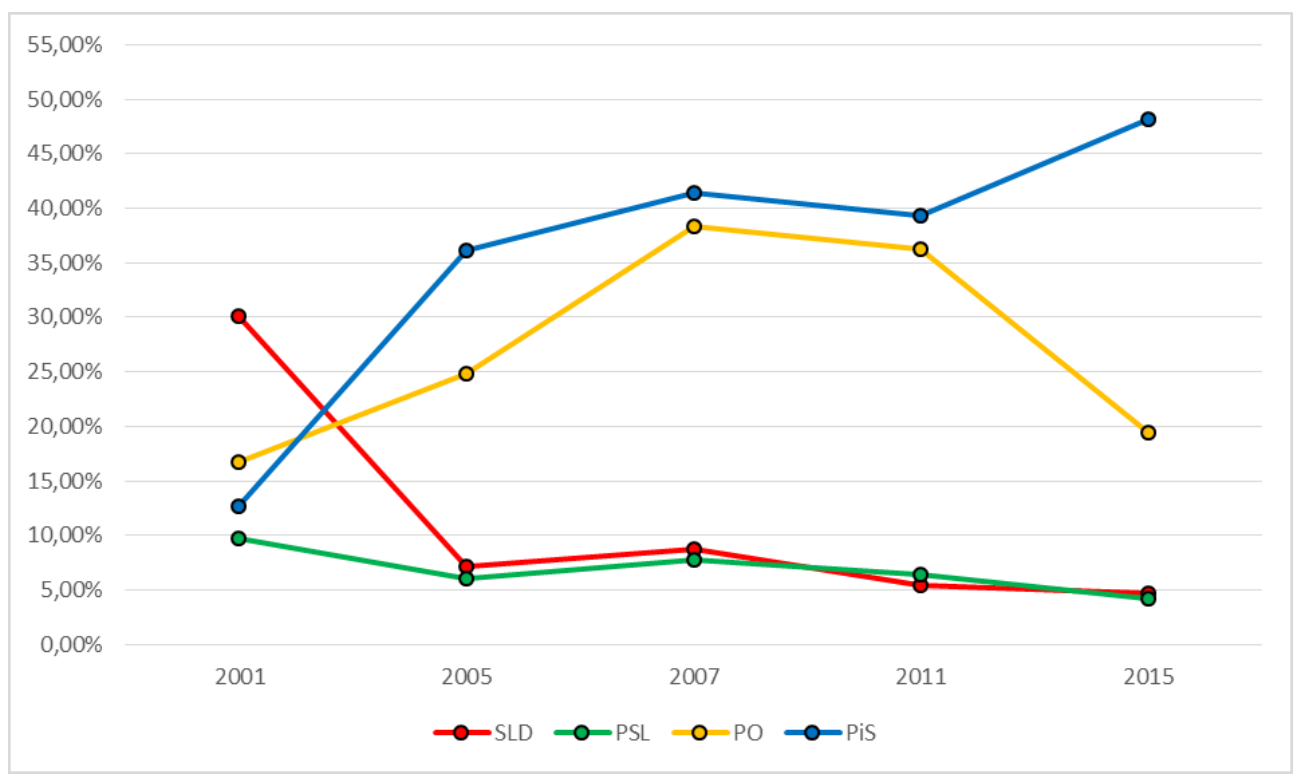

Zdroj: Vlastní graf autora dle NSD 2017, PKW 2015. 
Přestože se, jak již bylo zmíněno výše, v polském stranickém systému vyskytovali a stále vyskytují i jiní relevantní aktéŕi, čtyři strany, které jsou kontinuálně spojeny s polskou politikou tohoto tisíciletí, pravidelně získávají podporu naprosté většiny voličů, prričemž tato koncentrace byla nejsilnějšś v roce 2007. Graf 5 jednoznačně ukazuje, že přes určitý pokles však v posledních volbách PiS, PO, PSL a SLD i v roce 2015 získaly celkově přes $70 \%$ hlasů. Z hlediska regionálních rozdílů a srovnání s celostátními výsledky nelze (s výhradou týkající se roku 2005) pozorovat prriliš velké rozdíly, které by značily př́tomnost jiného, regionálně výrazně silnějšího subjektu.

\section{Graf 5: Podíl výsledku zkoumaných stran ve vojvodstvích (v \%)}

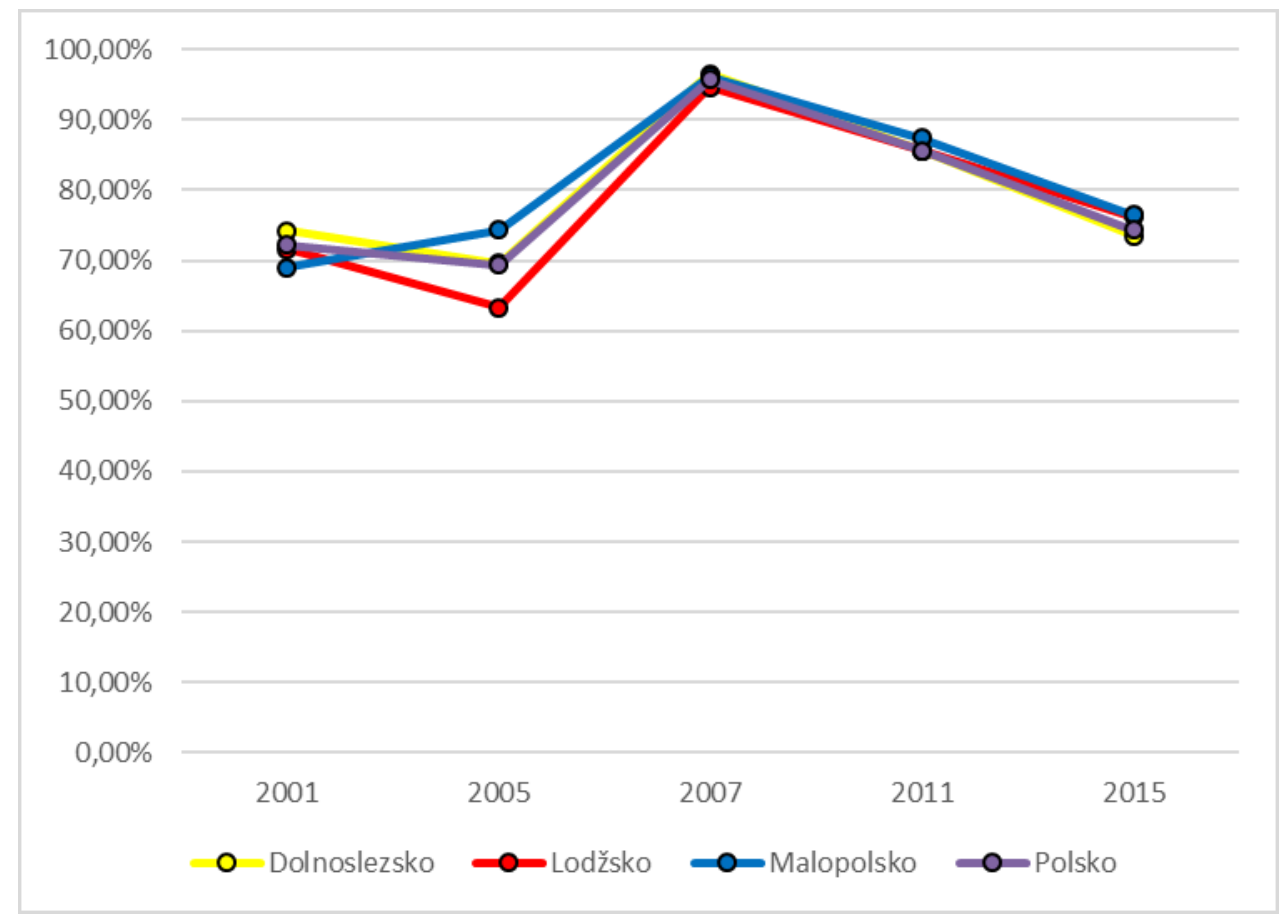

Zdroj: Vlastní graf autora dle NSD 2017, PKW 2015.

\section{PiS proti PO? Hledání souvislosti volební podpory stran}

Korelace volebních výsledků pomůže vyjasnit, do jaké míry se v prítomnosti podpory jedné strany (ne)objevuje podpora strany jiné, či zda žádná souvislost neexistuje. $V$ tomto prípadě bud zajímavé sledovat i vývoj v čase a prostoru, nebot' srovnání odlišných regionů umožňuje vysledovat př́padné odlišné zákonitosti v různých částech Polska. 
Vzhledem k významu Práva a spravedlnosti a Občanské platformy v polském stranickém systému je vhodné se podívat nejdřive na jejich vzájemný vztah volební podpory. Tabulka 3 ukazuje, že hodnota koeficientu se v průběhu sledovaného období zásadně změnila - v roce 2001 platilo, že v oblastech s podporou PiS se často vyskytovala podpora $\mathrm{PO}$, byt' tento vztah nebyl ve všech př́padech silný. Ve volbách 2007 nastal zásadní zlom, který se v následujících letech prohluboval a který naznačuje zásadní rozchod volební podpory obou stran. Nyní vcelku jednoznačně platí, že v místech podpory PiS se Občanské platformě nedaří a naopak. Lze rovněž říci, že tento vývoj koresponduje se situací na polské politické scéně, kde spor mezi oběma subjekty nabírá na intenzitě právě od období 2005-2007, tj. období nejprve menšinové a posléze koaliční vlády Práva a spravedlnosti se Sebeobranou a Ligou polských rodin, vi̊či níž stála Občanská platforma v jednoznačné opozici. Zda je změna způsobena tímto či jinými faktory na straně Práva a spravedlnosti, nebo zda došlo ke změně struktury volební podpory Občanské platformy, bude předmětem analýzy v další kapitole. Mezi jednotlivými regiony významnější změny pozorovat nelze.

Tabulka 3: Korelační analýza volebních výsledků PiS a PO ve zkoumaných vojvodstvích $\mathrm{v}$ letech 2001-2015 (N: Dolnoslezsko $=169$, Lodžsko $=177$, Malopolsko $=182$ )

\begin{tabular}{|c|c|c|c|c|c|}
\hline Vojvodství/volby & $\mathbf{2 0 0 1}$ & $\mathbf{2 0 0 5}$ & $\mathbf{2 0 0 7}$ & $\mathbf{2 0 1 1}$ & $\mathbf{2 0 1 5}$ \\
\hline Dolnoslezsko & 0,30 & 0,08 & $-0,51$ & $-0,60$ & $-0,76$ \\
\hline Lodžsko & 0,41 & 0,62 & $-0,33$ & $-0,52$ & $-0,75$ \\
\hline Malopolsko & 0,27 & 0,15 & $-0,51$ & $-0,59$ & $-0,68$ \\
\hline
\end{tabular}

Zdroj: Vlastní tabulka a výpočty autora.

Další vztahy subjektů již budou zmíněny podle jednotlivých vojvodství. V Dolním Slezsku se nejedná o hodnoty, které by ukazovaly na silný vztah mezi subjekty, a to s výjimkou u podstatné souvislosti volební podpory PO a PSL, která je záporná (viz Tabulka 4). Tyto subjekty, které spolu tvořily 8 let vládní koalici a spolupracují také na regionální úrovni, mají tedy z územního hlediska výrazně rozdílné zdroje volební podpory, což je ovšem poměrně logické vzhledem k odlišné ideové profilaci subjektů. 
Tabulka 4: Korelační analýza výsledků zkoumaných subjektů v Dolnoslezském vojvodství v letech 2001-2015 (N=169)

\begin{tabular}{|c|c|c|c|c|c|}
\hline Strany/volby & $\mathbf{2 0 0 1}$ & $\mathbf{2 0 0 5}$ & $\mathbf{2 0 0 7}$ & $\mathbf{2 0 1 1}$ & $\mathbf{2 0 1 5}$ \\
\hline PiS x SLD & 0,04 & $-0,03$ & $-0,33$ & $-0,04$ & $-0,26$ \\
\hline PiS x PSL & $-0,42$ & $-0,41$ & $-0,07$ & 0,02 & 0,14 \\
\hline PO x PSL & $-0,40$ & $-0,47$ & $-0,66$ & $-0,57$ & $-0,51$ \\
\hline PO x SLD & $-0,15$ & 0,06 & 0,05 & $-0,30$ & 0,08 \\
\hline PSL x SLD & $-0,57$ & $-0,34$ & $-0,38$ & $-0,30$ & $-0,30$ \\
\hline
\end{tabular}

Zdroj: Vlastní tabulka a výpočty autora.

Podobně lze hovořit o „ruském“ Lodžském vojvodství, kde se vztahy mezi volební podporou stran př́iliš neliší, většinou jsou ovšem o něco intenzivnější (opět zejména v př́padě Občanské platformy a Polské lidové strany, viz Tabulka 5).

Tabulka 5: Korelační analýza výsledků zkoumaných subjektů v Lodžském vojvodství v letech 2001-2015 (N=177)

\begin{tabular}{|c|c|c|c|c|c|}
\hline Strany/volby & $\mathbf{2 0 0 1}$ & $\mathbf{2 0 0 5}$ & $\mathbf{2 0 0 7}$ & $\mathbf{2 0 1 1}$ & $\mathbf{2 0 1 5}$ \\
\hline PiS x SLD & 0,25 & 0,13 & $-0,37$ & $-0,28$ & $-0,48$ \\
\hline PiS x PSL & $-0,43$ & $-0,68$ & $-0,20$ & $-0,06$ & 0,16 \\
\hline PO x PSL & $-0,63$ & $-0,59$ & $-0,77$ & $-0,76$ & $-0,62$ \\
\hline PO x SLD & 0,47 & 0,21 & 0,58 & 0,18 & 0,33 \\
\hline PSL x SLD & $-0,73$ & $-0,38$ & $-0,61$ & $-0,32$ & $-0,33$ \\
\hline
\end{tabular}

Zdroj: Vlastní tabulka a výpočty autora.

V Malopolsku je situace obdobná, je ovšem vhodné vidět kompletně negativní vztah podpory Práva a spravedlnosti s menšími stranami. V kombinaci s již zmíněnou výrazně negativní souvislostí jejích výsledků s PO a současnou dominancí PiS v tomto regionu to dotváří určitou představu vymezení tohoto konzervativního subjektu proti ostatním tradičním účastníkům polské stranické soutěže, která se kromě jeho nynější jednobarevné vlády projevuje i významně územně odloučeným elektorátem strany (viz Tabulka 6). 
Tabulka 6: Korelační analýza výsledků zkoumaných subjektů v Malopolském vojvodství v letech 2001-2015 ( $\mathrm{N}=182)$

\begin{tabular}{|c|c|c|c|c|c|}
\hline Strany/volby & $\mathbf{2 0 0 1}$ & $\mathbf{2 0 0 5}$ & $\mathbf{2 0 0 7}$ & $\mathbf{2 0 1 1}$ & $\mathbf{2 0 1 5}$ \\
\hline PiS x SLD & $-0,12$ & $-0,16$ & $-0,63$ & $-0,57$ & $-0,71$ \\
\hline PiS x PSL & $-0,52$ & $-0,67$ & $-0,22$ & $-0,20$ & $-0,23$ \\
\hline PO x PSL & $-0,47$ & $-0,53$ & $-0,66$ & $-0,60$ & $-0,47$ \\
\hline PO x SLD & $-0,20$ & 0,02 & 0,42 & 0,29 & 0,62 \\
\hline PSL x SLD & $-0,38$ & $-0,20$ & $-0,23$ & $-0,09$ & $-0,17$ \\
\hline
\end{tabular}

Zdroj: Vlastní tabulka a výpočty autora.

Graf 6 porovnává sílu vztahů ve vojvodstvích v absolutních hodnotách, tj. bez ohledu na pozitivní/negativní zaměření, lze pozorovat o něco častější silnější vztahy v Lodžském a Malopolském regionu, tj. východních částech Polska. Rozdíly ovšem nejsou príliš velké. Negativní vztahy výrazně převažují, a to ve všech vojvodstvích bez větších odlišností (viz Graf 7).

Graf 6: Hodnoty korelačního koeficientu dle de Vausovy stupnice ve zkoumaných vojvodstvích

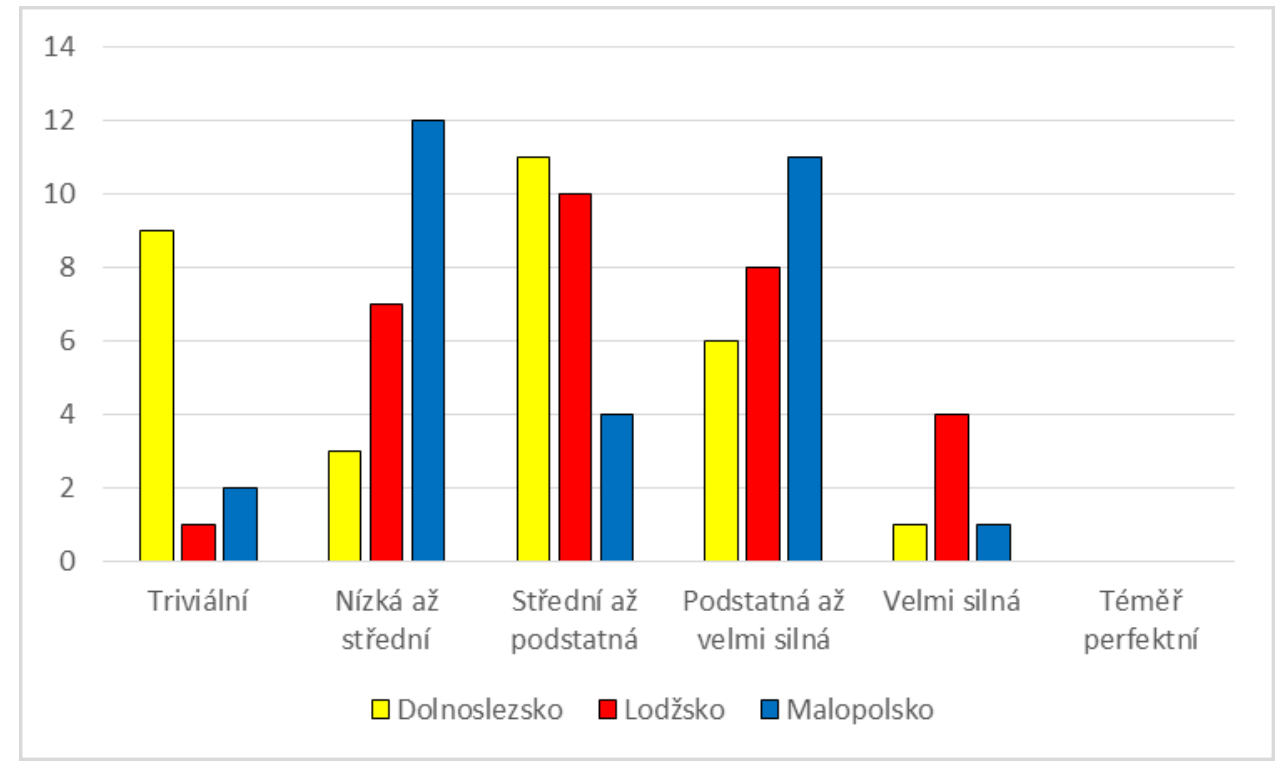

Zdroj: Vlastní graf a výpočty autora. 
Graf 7: Povaha vztahu mezi volebními výsledky zkoumaných stran

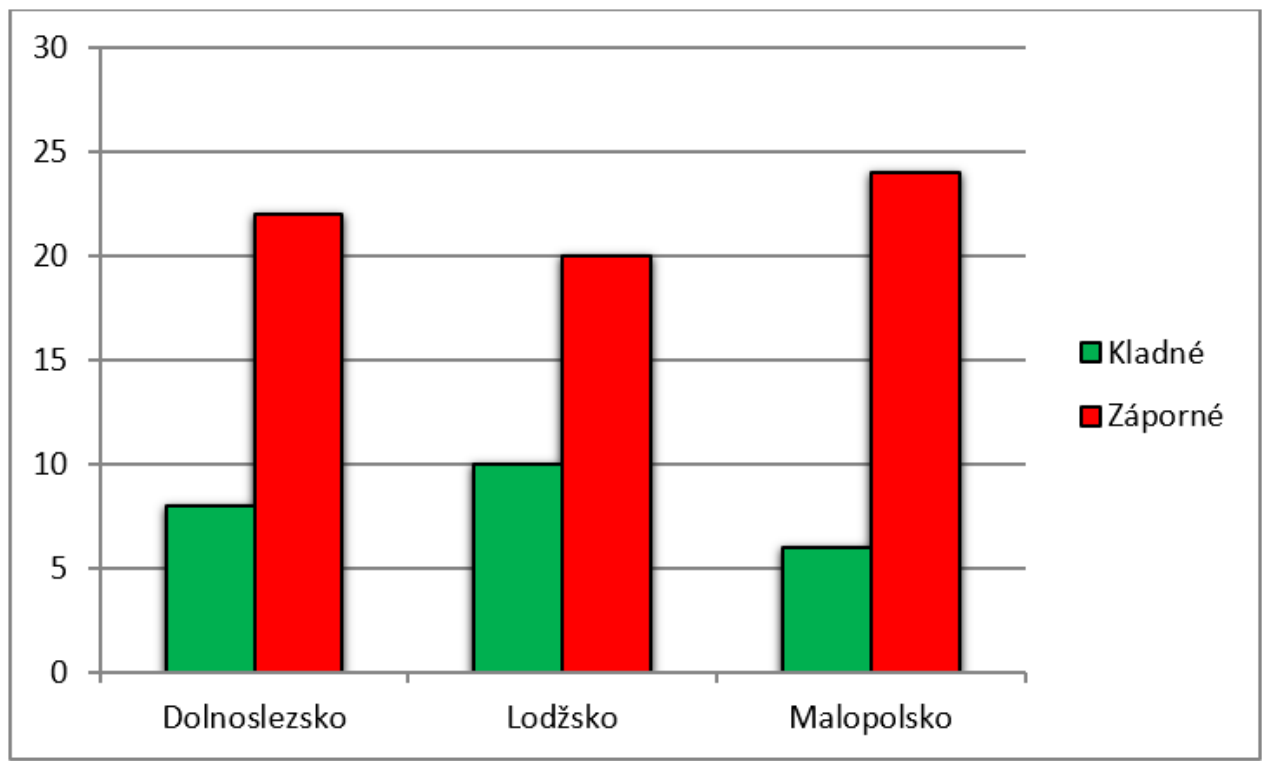

Zdroj: Vlastní graf a výpočty autora.

Korelační koeficient a jeho hodnoty je možné využít také ke zkoumání z pohledu síly vztahů v jednotlivých volbách, což dává možnost získat komplexní přehled o síle vztahů $v$ dlouhodobém pohledu (jde opět o absolutní hodnoty). Díky tomuto grafu lze vidět, že na západě Polska jsou souvislosti volebních výsledků dlouhodobě slabší než v ostatních vojvodstvích, kde je naopak silnější strukturace volební podpory (viz Graf 8). 
Graf 8: Souvislosti volebních výsledků stran ve zkoumaných vojvodstvích dle voleb

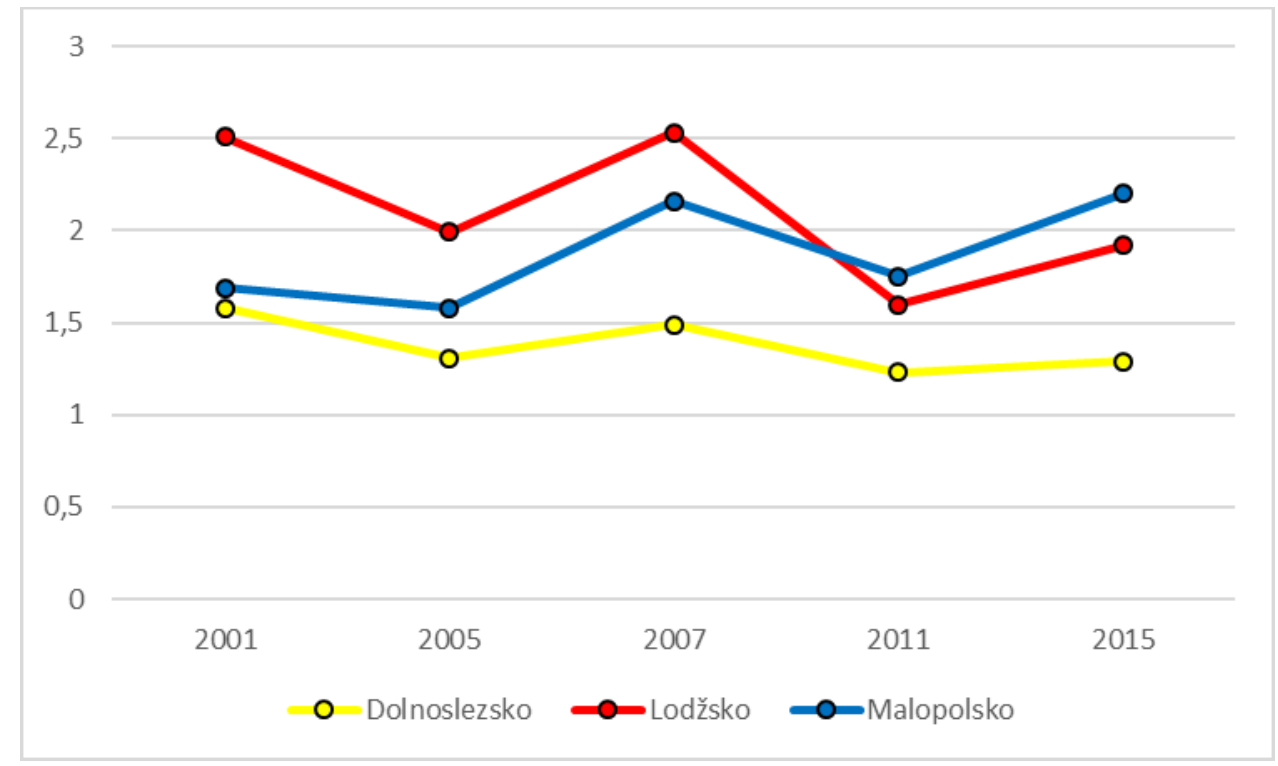

Zdroj: Vlastní graf a výpočty autora.

\section{Jednota v rozmanitosti? Analýza volební podpory stran $\mathrm{v}$ různých regionech}

Nyní budou zkoumány rozdíly v podpoře stran $\mathrm{v}$ různých regionech, a to pomocí většího počtu metod umožňujících komplexnější náhled na strukturu volební podpory, a pomocí toho naplnit cíle studie zmíněné v úvodu. Díky relativní shodě všech regionů v základních parametrech (viz výše) je možno učinit určitě generalizační závěry vzhledem $\mathrm{k}$ dalším polským vojvodstvím.

\section{a. Právo a spravedlnost}

$\mathrm{Na}$ základě poznatků z předchozí kapitoly již lze podporu PiS částečně popsat: od svého založení v roce 2001 tato strana zaznamenala růst podpory, který prozatím kulminoval $\mathrm{v}$ roce 2015. Silnější byla v Lodžském a zejména Malopolském vojvodství, ačkoli i v Dolním Slezsku nejsou její zisky malé. Vůči ostatním stranám má její volební podpora jednoznačně negativní souvislost, která se spíše posiluje.

Nyní ovšem budou použity další metody analýzy volební podpory, a to ve vzájemném srovnání regionů. Nejprve bude pozornost soustředěna na zobrazení stabilní volební (ne)podpory pomocí kartografického zobrazení. Mapa 4 ukazuje situaci v Dolnoslezském vojvodství. U Práva a spravedlnosti ovšem nastává problém, nebot' vzhledem ke změně elektorátu je zde pouze jedna obec (Jawor), 
která spadá do kategorie Území stabilní volební podpory. Z toho důvodu jsou zde (a v obou zbylých mapách) odlišně vyznačeny také USVP od roku 2007. Těch je výrazně více, zejména severněji v hustém pásu táhnoucím se od Lubušského vojvodství na severozápadě po Opolský region na východě. Neúspěšné oblasti jsou naopak především blízko hranic s Českou republikou.

\section{Mapa $4^{9}$ : Území stabilní volební podpory a nepodpory PiS v Dolnoslezském vojvodství}

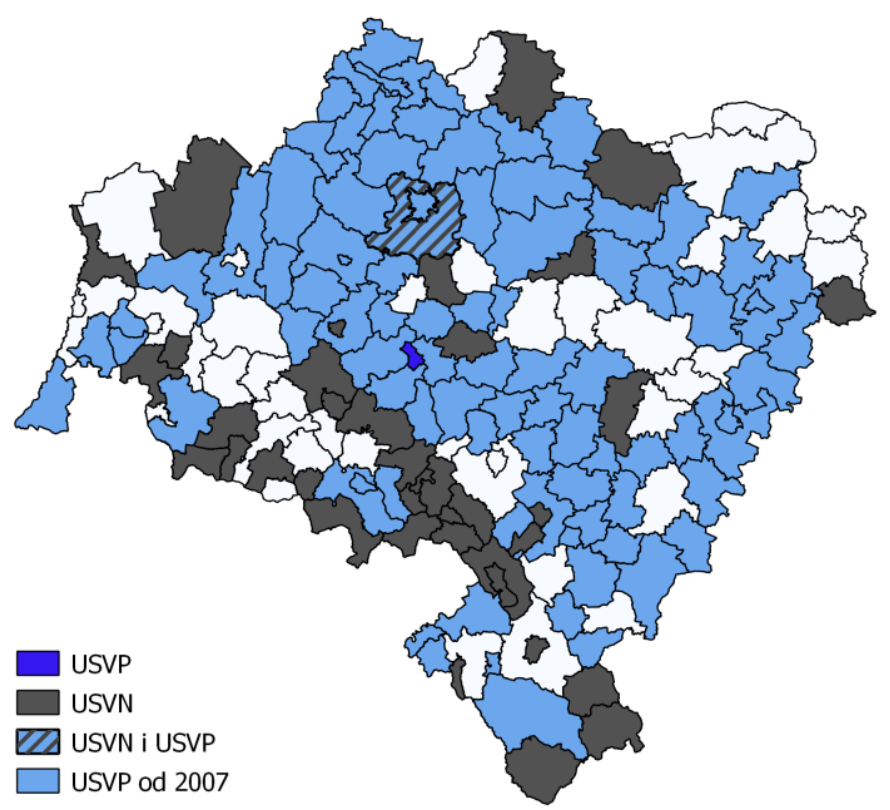

Zdroj: Vlastní mapa autora.

V Lodži a jejím okolí je situace v podstatě stejná, jedinou baštou PiS je Opoczno na východě regionu, od roku 2007 pak lze mluvit o poměrně rozsáhlém území, zejména na východ a jih od hlavního města. Stabilně neúspěšných oblastí je zde pouze několik gmin na jihozápadě a v okolí metropole (viz Mapa 5).

9 Venkovská gmina Lubin spadá jak do USVP od roku 2007, tak do USVN. Tento paradox je způsoben odlišným způsobem výpočtu obou ukazatelů. 
Mapa 5: Území stabilní volební podpory a nepodpory PiS v Lodžském vojvodství

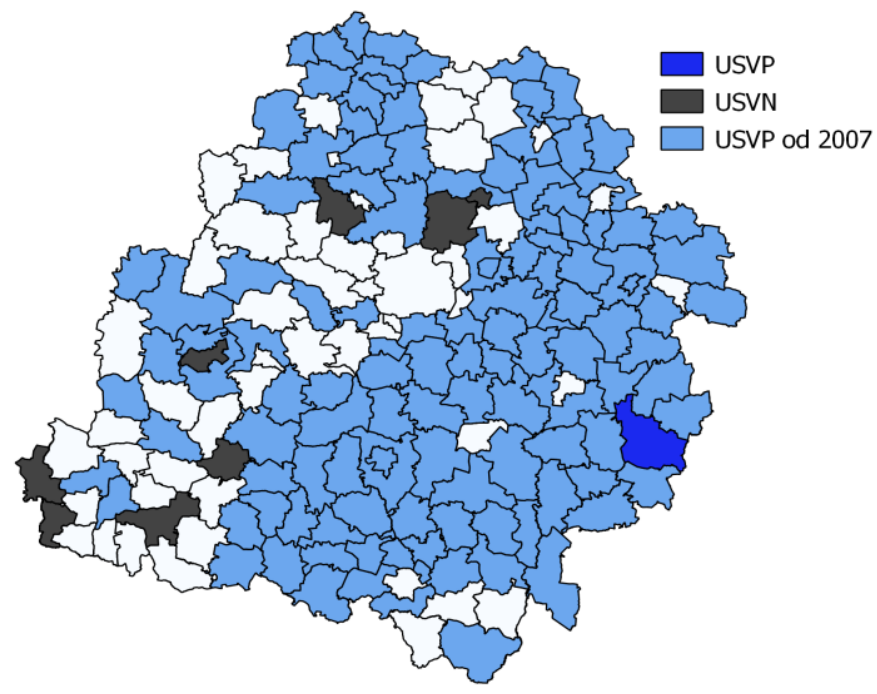

Zdroj: Vlastní mapa autora.

Mapa 6: Území stabilní volební podpory a nepodpory PiS v Malopolském vojvodství

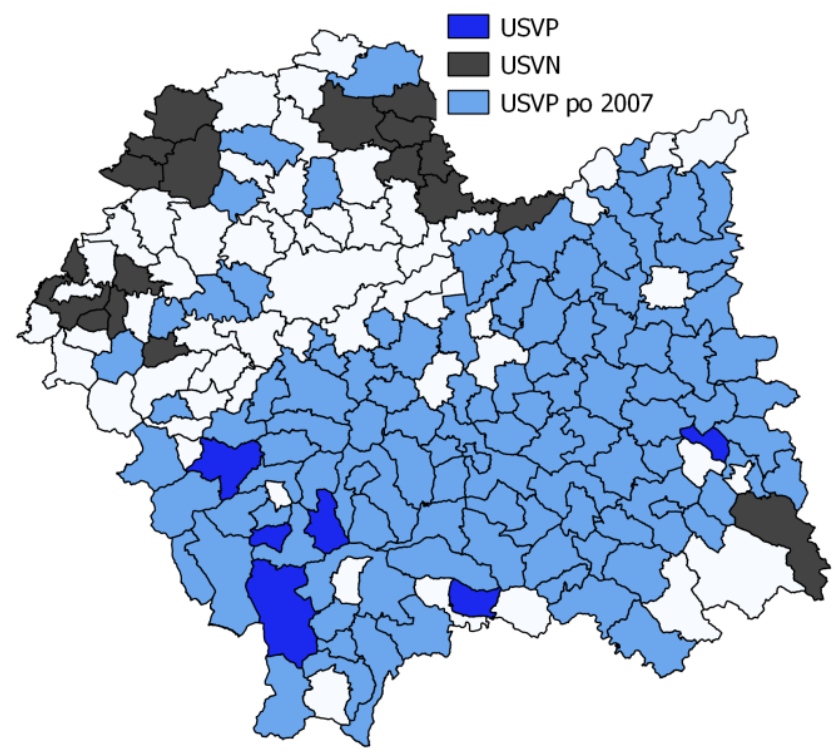

Zdroj: Vlastní mapa autora. 
Pouze Malopolsko nabízí poněkud pestřejší obrázek. Podle Mapy 6 je na jihu regionu blízko Tater a hranic se Slovenskem je několik obcí spadajících do USVP. Takřka celé území na jih a východ od Krakova je však stranickou baštou od roku 2007. Naopak na západ a na sever (patrná je souvislá oblast u hranic se Svatokřížským vojvodstvím) od centra regionu je nemalý počet samosprávních jednotek, ve kterých se PiS nedaří.

Mapy tedy v zásadě naznačují, že změna ve vztahu volebních výsledků PiS a PO je spíše vlivem obratu u první ze zmíněných stran. Je pochopitelné, že s kratším časovým úsekem je ÚSVP rozsáhlejší, nicméně tento nárůst je velmi markantní a značí rozsáhlejší územní bázi, na kterou se strana může v posledním desetiletí spolehnout, než aby svoji podporu získávala koncentrovaně v několika oblastech.

Tomu nahrávají i další data o prostorových rozdílech ve volební podpoře. Tabulka 7 ukazuje zjištěné hodnoty variačního a Giniho koeficientu které popisují znatelnou změnu směrem $\mathrm{k}$ rovnoměrnějšímu rozprostření volební podpory, a to zejména ve srovnání let 2005 a 2007. Zejména díky Giniho koeficientu je vidět, že šlo o zásadní přesun od podpory koncentrované ve velkých městech k obdobným ziskům naprríč spektrem gmin. Ani zde ovšem nelze hovořit o podstatném rozdílu mezi vojvodstvími, vývoj je všude podobný.

Tabulka 7: Hodnoty variačního a Giniho koeficientu pro PiS ve volbách 2001-2015

\begin{tabular}{|c|l|l|l|l|l|l|l|l|l|l|}
\hline Volby & \multicolumn{2}{|c|}{2001} & \multicolumn{2}{c|}{2005} & \multicolumn{2}{c|}{2007} & \multicolumn{2}{c|}{2011} & \multicolumn{2}{c|}{2015} \\
\hline & VAR & GINI & VAR & GINI & VAR & GINI & VAR & GINI & VAR & GINI \\
\hline Dolnoslezsko & 0,38 & 0,58 & 0,26 & 0,54 & 0,19 & 0,35 & 0,19 & 0,35 & 0,18 & 0,27 \\
\hline Lodžsko & 0,66 & 0,64 & 0,42 & 0,64 & 0,18 & 0,18 & 0,21 & 0,18 & 0,16 & 0,16 \\
\hline Malopolsko & 0,52 & 0,52 & 0,33 & 0,52 & 0,22 & 0,22 & 0,26 & 0,25 & 0,19 & 0,22 \\
\hline
\end{tabular}

Zdroj: Vlastní tabulka a výpočty autora.

Vzhledem k výrazné změně je vhodné tento ukazatel doprovodit ještě další statistikou: podílem zisku v hlavních městech vojvodství na celkovém zisku PiS v regionech. Již od prvních voleb v roce 2001 jsou pro Právo a spravedlnost tato velkoměsta $^{10}$ stále méně významná z hlediska celkového výsledku. V tomto případě je ovšem větší rozdíl již o jedno volební období dříve, mezi roky 2001 a 2005 (viz Graf 9).

${ }^{10} \mathrm{~V}$ každém z nich žije přes 600 tisíc obyvatel, jedná se o tři ze čtyř největších měst v Polsku. 
Graf 9: Podíl hlavních měst vojvodství na celkovém výsledku Práva a spravedlnosti ve zkoumaných regionech v letech 2001-2015

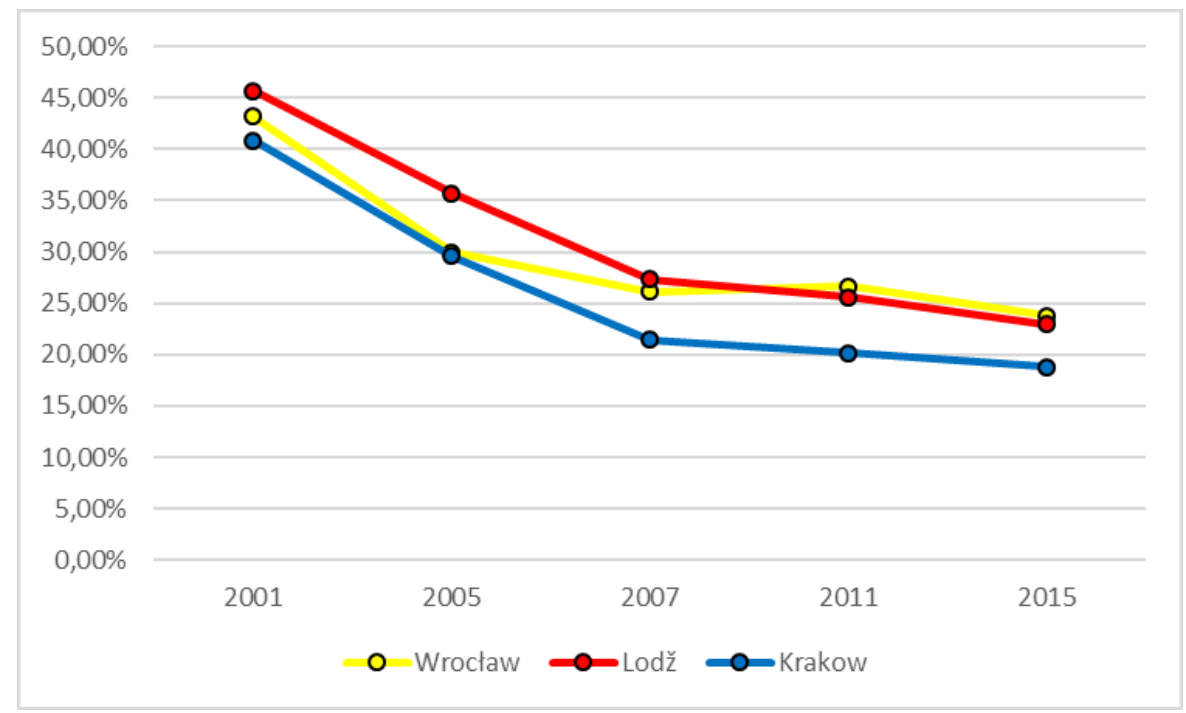

Zdroj: Vlastní graf autora.

Poslední zkoumaným parametrem je stabilita, resp. korelace výsledků napříc volbami. Ta u PiS v Dolním Slezsku od roku 2005 prudce stoupla a nyní kulminuje téměr dokonalou shodou (viz Tabulka 8). Nelze argumentovat pouze časovou blízkostí prezidentských a parlamentních voleb v roce 2015, nebot' při totožné situaci deset let předtím byla souvislost výsledků podstatně slabší.

Tabulka 8: Korelační analýza volebních výsledků PiS v Dolnoslezském vojvodství v letech 2001-2015 (S = volby do Sejmu, šedá výplň = hodnoty nad 0,90 vč., $\mathbf{N}=169$ )

\begin{tabular}{|c|c|c|c|c|c|}
\hline Volby & S2001 & S2005 & S2007 & S2011 & S2015 \\
\hline EP04 & 0,27 & 0,40 & $-0,16$ & $-0,13$ & $-0,23$ \\
\hline EP09 & $-0,05$ & 0,35 & 0,78 & 0,77 & 0,75 \\
\hline EP14 & $-0,18$ & 0,11 & 0,72 & 0,81 & 0,87 \\
\hline PREZ05 & 0,26 & 0,52 & 0,66 & 0,58 & 0,50 \\
\hline PREZ10 & $-0,26$ & 0,11 & 0,87 & 0,67 & 0,93 \\
\hline PREZ15 & $-0,34$ & 0,01 & 0,78 & 0,84 & 0,95 \\
\hline
\end{tabular}

Zdroj: Vlastní tabulka a výpočty autora. 
V podstatě stejná situace je také v Lodžském regionu. Tabulka 9 ukazuje, že vazby z počátku existence PiS se jednoznačně přerušily po polovině minulého desetiletí ve prospěch nových a silnějších vztahů.

Tabulka 9: Korelační analýza volebních výsledků PiS v Lodžském vojvodství v letech 2001-2015 (S = volby do Sejmu šedá výplň = hodnoty nad 0,90 vč., $\mathbf{N}=177$ )

\begin{tabular}{|c|c|c|c|c|c|}
\hline Volby & S2001 & S2005 & S2007 & S2011 & S2015 \\
\hline EP04 & 0,55 & 0,70 & $-0,04$ & $-0,17$ & $-0,39$ \\
\hline EP09 & $-0,03$ & 0,02 & 0,56 & 0,60 & 0,61 \\
\hline EP14 & $-0,22$ & $-0,16$ & 0,60 & 0,74 & 0,83 \\
\hline PREZ05 & 0,48 & 0,55 & 0,29 & 0,19 & $-0,04$ \\
\hline PREZ10 & $-0,29$ & $-0,23$ & 0,75 & 0,84 & 0,88 \\
\hline PREZ15 & $-0,38$ & $-0,30$ & 0,68 & 0,83 & 0,92 \\
\hline
\end{tabular}

Zdroj: Vlastní tabulka a výpočty autora.

Nejméně je výše zmíněný jev př́tomný v Malopolsku, kde panuje určitá kontinuita i mezi některými staršími volbami, což je zejména vidět u prezidentských voleb roce 2005, kde na výsledky Lecha Kaczyńského v prvním kole (posléze vítězných) prezidentských voleb strana do značné míry navazuje do současnosti. $V$ prípadě voleb do Evropského parlamentu to však lze říci až od hlasování v roce 2009 (viz Tabulka 10).

Tabulka 10: Korelační analýza volebních výsledků PiS v Malopolském vojvodství v letech 2001-2015 (S = volby do Sejmu šedá výplň = hodnoty nad 0,90 vč., $\mathrm{N}=$ 182)

\begin{tabular}{|c|c|c|c|c|c|}
\hline Volby & S2001 & S2005 & S2007 & S2011 & S2015 \\
\hline EP04 & 0,58 & 0,55 & 0,07 & 0,06 & $-0,03$ \\
\hline EP09 & 0,21 & 0,41 & 0,90 & 0,90 & 0,91 \\
\hline EP14 & 0,20 & 0,31 & 0,75 & 0,79 & 0,81 \\
\hline PREZ05 & 0,36 & 0,56 & 0,81 & 0,84 & 0,78 \\
\hline PREZ10 & 0,03 & 0,19 & 0,88 & 0,91 & 0,92 \\
\hline PREZ15 & $-0,02$ & 0,12 & 0,85 & 0,87 & 0,93 \\
\hline
\end{tabular}

Zdroj: Vlastní tabulka a výpočty autora.

Ze zjištěných poznatků o volební podpoře Práva a spravedlnosti lze vyvodit závěr, že podpora strany nemá z hlediska struktury v podstatě žádná regionální specifika a vyvijí se velmi podobným způsobem. Společným jmenovatelem, který je možno zmínit jako nejpodstatnější zjištění, je přelomové období ohraničené 
volbami 2005 a 2007. Právě tehdy lze pozorovat trendy, které pro podporu PiS platí dosud.

\section{P̌̌IČINY ZMĚNY VOLEBNÍ PODPORY PIS V KONTEXTU VÝSLEDKŮ LPR}

\section{A SEBEOBRANY}

Co bylo důvodem této změny? Pro konkrétnějšś zjištění, která by vysvětlovala přerod Práva a spravedlnosti ze subjektu s nevyrovnanou podporou v rámci regionů ve stranu, která je schopna uspět prakticky všude a jejíž elektorát je prakticky negativem podpory PO (viz kapitola 6) je nutné se vrátit k období 20052007.

Z grafu 1 je zřejmé výrazné posílení PiS a PO a jejich definitivního etablování na pozici hlavních účastníků stranické soutěže, $\mathrm{k}$ čemuž došlo právě $\mathrm{v}$ této době. Výraznější byl nárůst podpory pro Občanskou platformu. U ní však, jak bude potvrzeno níže, nedošlo $\mathrm{k}$ významnější změně $\mathrm{v}$ prostorové struktuře volební podpory, u Práva a spravedlnosti je tomu presně naopak.

Vysvětlení je nepochybně kombinací více faktorů, pro účely této studie se nabízí zkoumat vliv volebních výsledků ostatních stran, konkrétně dvou, které uspěly ve volbách 2001 a 2005 - Ligy polských rodin a Sebeobrany (podrobněji o obou viz Breindl 2003 a Cabada et al. 2013: 61-67). Tyto subjekty ztratily ve volbách v roce 2007 celkem více než 16,5 \% hlasů a ukončily své působení v dolní komoře parlamentu. Jejich politická performance $\mathrm{v}$ př́edchozím dvouletém volebním období vykazovala kompatibilitu s PiS - po volbách 2005 nejprve podpořily její menšinovou vládu, do její druhé vlády dokonce prŕmo vstoupily (Balík et al. 2011: 150-152). Zároveň strany nebyly ideologicky př́liš vzdálené, $\mathrm{v}$ př́padě LPR a Sebeobrany byla ovšem patrná profilace na konfliktní linii městovenkov ve prospěch druhé ze jmenovaných oblastí (Fiala, Herbut 2003: 122-123). Nabízí se tedy logický předpoklad, že zmíněné jevy spolu souvisí.

Pro potvrzení předpokladu bude provedena nejprve korelační analýza volebních výsledků LPR a Sebeobrany ve zkoumaných regionech z roku 2005 s těmi, kterých dosáhly ostatní strany o dva roky později. Tabulka 11 dokládá, že určitá kladná souvislost mezi výsledky existuje, a to zejména ve vztahu volebních zisků Ligy polských rodin a PiS. V menší míre to platí u Sebeobrany, která vykazuje vyšší shodu s PSL, což není prriliš překvapující, nebot' navzdory odlišné pozici ve stranické soutěži šlo $\mathrm{v}$ obou prrípadech o agrárně zaměřené subjekty s jednoznačnou profilací na venkov, lišící se zejména mírou radikality a výrazně populistickým akcentem v prŕpadě Sebeobrany (Hloušek a Kopeček 2010: 117123). 
Tabulka 11: Korelační analýza volebních výsledků LPR, Sebeobrany (2005) a ostatních stran (2007) ve zkoumaných regionech

\begin{tabular}{|c|c|c|c|c|c|}
\hline Vojvodství & Strana & PiS 2007 & PO 2007 & PSL 2007 & SLD 2007 \\
\hline \multirow{2}{*}{ Dolnoslezsko } & LPR 2005 & 0,28 & $-0,24$ & 0,07 & $-0,12$ \\
\cline { 2 - 6 } & S 2005 & 0,25 & $-0,70$ & 0,59 & $-0,24$ \\
\hline \multirow{2}{*}{ Lodžsko } & LPR 2005 & 0,24 & 0,11 & $-0,18$ & $-0,07$ \\
\cline { 2 - 6 } & S 2005 & 0,23 & $-0,73$ & 0,49 & $-0,44$ \\
\hline \multirow{2}{*}{ Malopolsko } & LPR 2005 & 0,53 & $-0,32$ & $-0,09$ & $-0,41$ \\
\cline { 2 - 6 } & S 2005 & $-0,05$ & $-0,55$ & 0,49 & 0,06 \\
\hline
\end{tabular}

Zdroj: Vlastní tabulka a výpočty autora.

Až na jednu výjimku je tedy možno pozorovat pozitivní souvislost PiS a obou dříve významných aktérů polské politiky. Tomuto možnému vztahu tedy bude ještě věnována pozornost. Ze samotné korelace pochopitelně nelze vyvozovat kauzalitu, tj. že voliči LPR a Sebeobrany přešli v roce 2007 k Právu a Spravedlnosti, byt' se tato hypotéza jeví jako pravděpodobná. Výsledky těchto stran tedy budou podrobeny ještě regresní analýze. Jejím cílem je zjištění, o kolik rostla podpora PiS (ta představuje závislou proměnnou) v oblastech s podporou těchto subjektů (nezávislé proměnné) o dva roky dříve a zda existují významnější rozdíly mezi zkoumanými regiony.

Z hodnot indexu determinace je patrné, že volební výsledky LPR a Sebeobrany nemohou sloužit jako jednoznačné vysvětlení pro zisky PiS v následujících volbách, nebot' naměřené hodnoty jsou poměrně nízké. Zajímavý je ovšem rozdíl mezi Malopolským vojvodstvím a zbylými regiony (viz Tabulka 12). Oblast západní Haliče je ze tří vojvodství jediným, kde LPR ve volbách 2005 nad Sebeobranou zvítězila (NSD 2017).

Tabulka 12: Index determinace regresní analýzy volebních výsledků Ligy polských rodin, Sebeobrany (2005) a Práva a spravedlnosti (2007)

\begin{tabular}{|c|c|}
\hline Vojvodství & Hodnota indexu \\
\hline Dolnoslezsko & 0,12 \\
\hline Lodžsko & 0,15 \\
\hline Malopolsko & 0,28 \\
\hline
\end{tabular}

Zdroj: Vlastní tabulka a výpočty autora.

Tabulka 13, která ukazuje výsledky analýzy, přináší potvrzení předchozích dat, se zvyšující se podporou Ligy polských rodin na úrovni gmin se zvyšuje také podpora Práva a spravedlnosti, což platí zejména v Malopolsku, kde s každým procentem pro Ligu posílilo PiS o dva roky později téměř totožně. U Sebeobrany je naopak tento vztah výrazně slabší. 
Tabulka 13: Výsledky regresní analýzy vysvětlujících volební podporu Práva a spravedlnosti (2007) pomocí volebních výsledků Ligy polských rodin a Sebeobrany (2005)

\begin{tabular}{|c|c|c|c|}
\hline Proměnná & Vojvodství & B & Beta \\
\hline \multirow{3}{*}{ Konstanta } & Dolnoslezsko & 22,31 & \\
\cline { 2 - 4 } & Lodžsko & 30,94 & \\
\cline { 2 - 4 } & Malopolsko & 35,83 & \\
\hline \multirow{3}{*}{ LPR 2005 } & Dolnoslezsko & 0,56 & 0,24 \\
\cline { 2 - 4 } & Lodžsko & 0,42 & 0,31 \\
\cline { 2 - 4 } & Malopolsko & 0,96 & 0,53 \\
\hline \multirow{3}{*}{ Sebeobrana 2005 } & Dolnoslezsko & 0,15 & 0,20 \\
\cline { 2 - 4 } & Lodžsko & 0,21 & 0,30 \\
\cline { 2 - 4 } & Malopolsko & 0,00 & 0,00 \\
\hline
\end{tabular}

Zdroj: Vlastní tabulka a výpočty autora.

Pomocí zvolených nástrojů lze tedy předpoklad o vlivu propadu dvou do té doby významných článků polského stranického systému potvrdit v případě Ligy polských rodin, kde podle všech indicii ${ }^{11}$ skutečně dochází $\mathrm{k}$ přesunu významné části voličů. U Sebeobrany korelační a regresní analýza předpoklady nepotvrzuje, a to zejména v oblasti Malopolska.

\section{b. Občanská platforma}

Hlavní vládní strana v letech 2007-2015 a největší soupeř PiS je silnější na západě země, byt' i v Dolním Slezsku ztratil v posledních volbách pozici nejsilnějš́̌́ho subjektu. Vztah volební podpory k ostatním stranám není jednoznačně negativní - s SLD je pozitivní souvislost, a tedy určité sdílení volebních bašt, vcelku časté.

U map se částečně opakuje situace se zobrazením podpory PiS, přesto je však o něco rozmanitějš́í. V Dolním Slezsku se PO mohla spolehnout na Wrocław (kromě ní ještě Brzeg Dolny ležící severozápadně od nî), kde dosahoval vždy vysokých výsledků. Do oblasti volební nepodpory stabilně spadá nemalá část obcí, tvořící široký pás od Orlických hor na sever a západ od hlavního města vojvodství. Rozlohou menší gminy, které v něm tvoří bílá místa, jsou většinou jednotky městského charakteru (podobně jako v ČR např. Brno-město v okrese Brno-venkov). V nich dlouhodobá situace PO není jednoznačná (viz Mapa 7).

${ }^{11}$ Není bez zajímavosti, že do stejného období spadá také určitý posun v polské mediální sféře. Radio Maryja, vlivná klerikálně-konzervativní rozhlasová stanice, do roku 2006 výrazně podporovala LPR (Stenzelová 2016: 25-26), poté se ovšem její prŕízeň postupně přesunula $\mathrm{k}$ PiS (Forward.com 2010). 
Mapa 7: Území stabilní volební podpory a nepodpory PO v Dolnoslezském

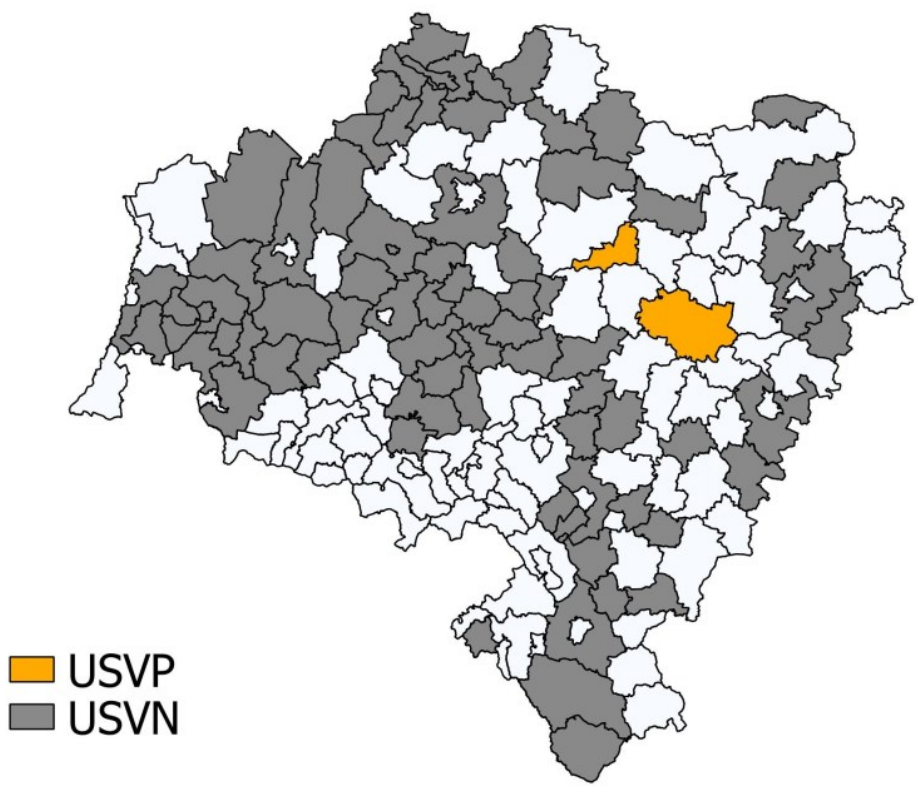

vojvodství

Zdroj: Vlastní mapa autora.

Totéž, dokonce ještě výrazněji platí i pro Lodžské vojvodství. Také zde je pro stranu zásadní výsledek v centru regionu, popř. v jeho blízkém okolí. Většina obcí se naopak stabilně nachází pod průměrným výsledkem (viz Mapa 8). 


\section{Mapa 8: Území stabilní volební podpory a nepodpory PO v Lodžském vojvodství}

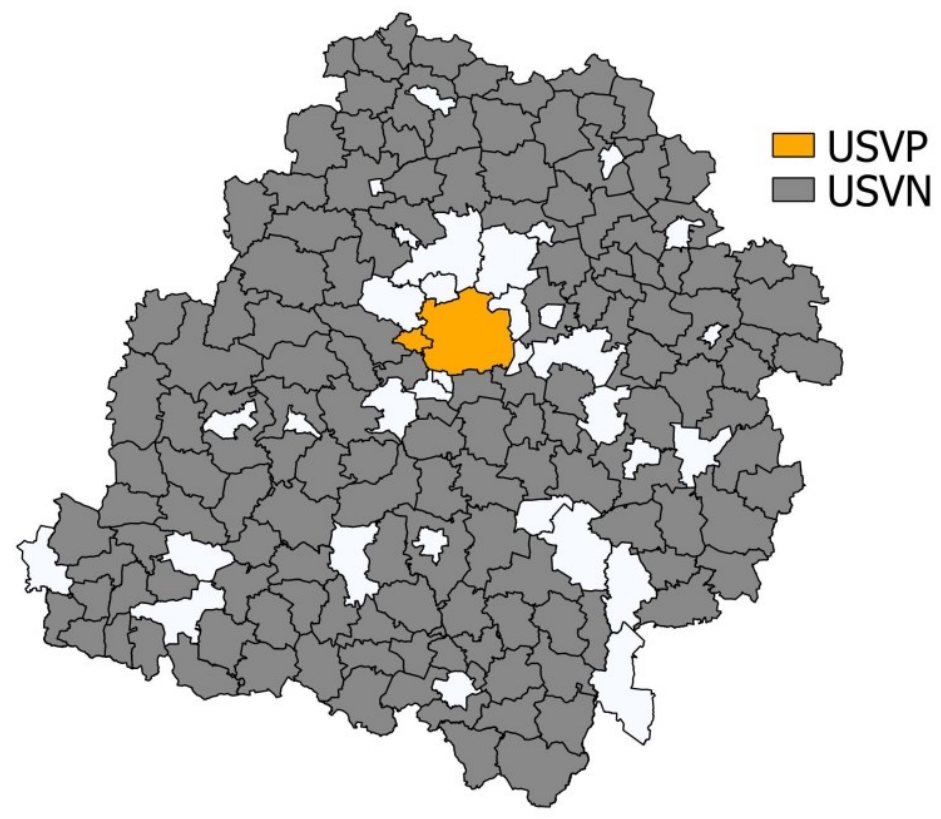

Zdroj: Vlastní mapa autora.

Mapa 9 ukazuje, že Malopolsko, pro platformu nejméně úspěšný ze zkoumaných regionů, je svou prostorovou strukturou stabilní (ne)podpory bližší spíše Dolnímu Slezsku. Tradičně se straně daří v Krakově, dále v sousední obci Zabierzów a zajímavá je také oblast na jihu u slovenských hranic. Jedná se o Szczawnicu, mj. proslulou lázeňskou oblast. Jinak lze hovořit o rozdělení přibližně na neúspěšný sever a východ a dlouhodobě nevyčnívající jih a západ Malopolska.

Z hlediska vizualizace volební podpory je tedy seznam stabilně úspěšných oblastí podobně krátký, jako $\mathrm{v}$ př́padě PiS. Zde je to ovšem způsobeno jiným profilem strany, která zůstala stabilně fixována zejména do hustěji obydlených oblastí. 
Mapa 9: Území stabilní volební podpory a nepodpory PO v Malopolském vojvodství

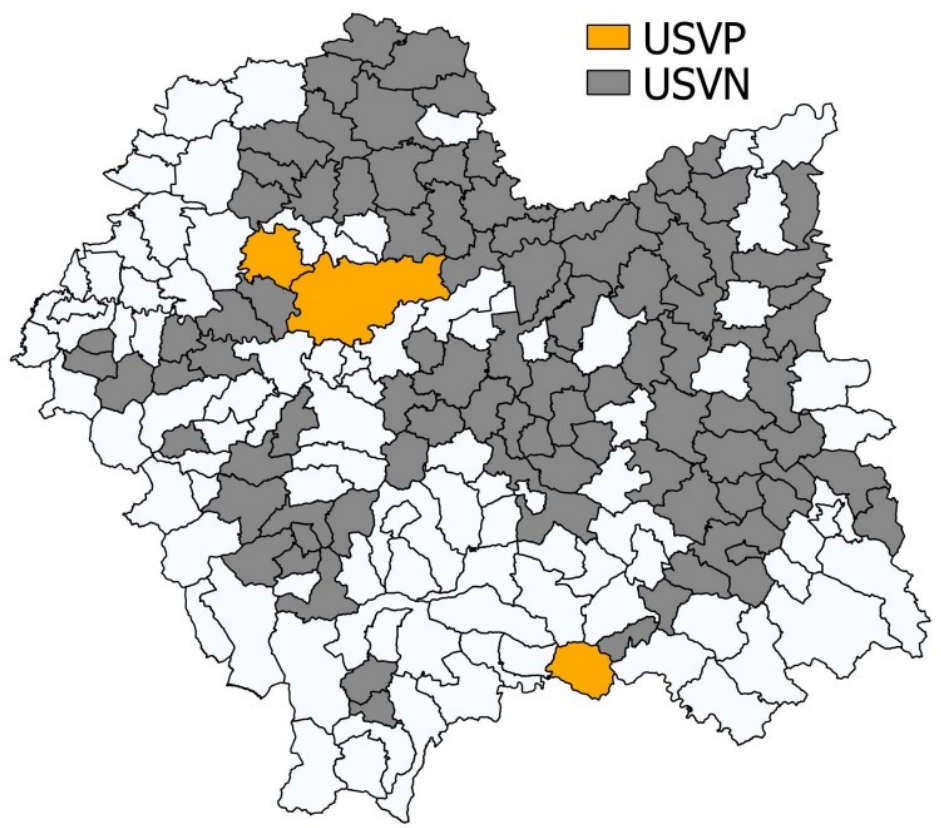

Zdroj: Vlastní mapa autora.

Prostorové rozdíly ve volební podpoře nejsou PO extrémní a strana v tomto směru neprošla během své existence výraznou změnou, jako tomu bylo u PiS. Pouze u Dolního Slezska lze také nalézt významnější strukturální rozdíl oproti zbylým dvěma regionům, při zohlednění velikosti obcí Giniho koeficientem však tato odlišnost mizí (viz Tabulka 14).

Tabulka 14: Hodnoty variačního a Giniho koeficientu pro PO ve volbách 20012015

\begin{tabular}{|c|c|c|c|c|c|c|c|c|c|c|}
\hline Volby & \multicolumn{2}{|c|}{2001} & \multicolumn{2}{c|}{2005} & \multicolumn{2}{c|}{2007} & \multicolumn{2}{c|}{2011} & \multicolumn{2}{c|}{2015} \\
\hline & VAR & GINI & VAR & GINI & VAR & GINI & VAR & GINI & VAR & GINI \\
\hline Dolnoslezsko & 0,43 & 0,50 & 0,34 & 0,54 & 0,19 & 0,49 & 0,18 & 0,47 & 0,23 & 0,51 \\
\hline Lodžsko & 0,65 & 0,66 & 0,63 & 0,60 & 0,47 & 0,59 & 0,46 & 0,59 & 0,46 & 0,56 \\
\hline Malopolsko & 0,57 & 0,57 & 0,49 & 0,58 & 0,38 & 0,53 & 0,39 & 0,53 & 0,45 & 0,55 \\
\hline
\end{tabular}

Zdroj: Vlastní tabulka a výpočty autora.

Jak je na tom Občanská platforma se vzájemnými vztahy volební podpory? Tabulka 15 odhaluje, že v Dolním Slezsku vazba mezi staršími a novějšími 
výsledky stále zůstává podstatná, a to u obou typů voleb. Je zde tedy opět vidět absence zásadního zlomu, jako u Práva a spravedlnosti (byt' mírné všeobecné posílení korelace mezi volbami 2005 a 2007 je viditelné), a přirozenější vývoj aspektů volební podpory.

Tabulka 15: Korelační analýza volebních výsledků PO v Dolnoslezském vojvodství v letech 2001-2015 ( $\mathrm{S}=$ volby do Sejmu, šedá výplň = hodnoty nad 0,90 vč., $\mathrm{N}=$ 169)

\begin{tabular}{|c|c|c|c|c|c|}
\hline Volby & S2001 & S2005 & S2007 & S2011 & S2015 \\
\hline EP04 & 0,62 & 0,70 & 0,73 & 0,64 & 0,47 \\
\hline EP09 & 0,51 & 0,67 & 0,80 & 0,69 & 0,58 \\
\hline EP14 & 0,54 & 0,62 & 0,84 & 0,84 & 0,77 \\
\hline PREZ05 & 0,51 & 0,67 & 0,85 & 0,75 & 0,65 \\
\hline PREZ10 & 0,34 & 0,48 & 0,83 & 0,81 & 0,80 \\
\hline PREZ15 & 0,24 & 0,35 & 0,67 & 0,72 & 0,81 \\
\hline
\end{tabular}

Zdroj: Vlastní tabulka a výpočty autora.

V Lodžském vojvodství je stabilita $\mathrm{z}$ hlediska času ještě výraznější, vrcholem byl rok 2007, k jejíž volební podpoře v tomto hlasování měla strana silný vztah $\mathrm{v}$ podstatě ve všech ostatních volbách a $\mathrm{v}$ mnoha případech se přiblížila téměr perfektní shodě (viz Tabulka 16).

Tabulka 16: Korelační analýza volebních výsledků PO v Lodžském vojvodství v letech 2001-2015 (S = volby do Sejmu, šedá výplň = hodnoty nad 0,90 vč., $N=$ 177)

\begin{tabular}{|c|c|c|c|c|c|}
\hline Volby & S2001 & S2005 & S2007 & S2011 & S2015 \\
\hline EP04 & 0,78 & 0,89 & 0,90 & 0,83 & 0,79 \\
\hline EP09 & 0,72 & 0,84 & 0,94 & 0,92 & 0,89 \\
\hline EP14 & 0,66 & 0,82 & 0,90 & 0,92 & 0,91 \\
\hline PREZ05 & 0,75 & 0,89 & 0,94 & 0,90 & 0,86 \\
\hline PREZ10 & 0,67 & 0,81 & 0,92 & 0,92 & 0,93 \\
\hline PREZ15 & 0,47 & 0,63 & 0,75 & 0,80 & 0,87 \\
\hline
\end{tabular}

Zdroj: Vlastní tabulka a výpočty autora.

Nejméně úspěšný region PO vykazuje velmi výraznou změnu mezi parlamentními volbami 2001 a 2005. Tento poznatek je možné dát do souvislosti s faktem, že v roce 2001 zde Občanská platforma ještě porazila PiS, později již byla $\mathrm{v}$ regionu „až druhou nejsilnější stranou. K určitému upevnění a stabilizaci volební podpory zde tedy došlo přibližně v tomto období (viz Tabulka 17). 
Tabulka 17: Korelační analýza volebních výsledků PO v Malopolském vojvodství v letech 2001-2015 (S = volby do Sejmu, šedá výpln̆ = hodnoty nad 0,90 vč., $\mathrm{N}=$ 182)

\begin{tabular}{|c|c|c|c|c|c|}
\hline Volby & S2001 & S2005 & S2007 & S2011 & S2015 \\
\hline EP04 & 0,40 & 0,66 & 0,66 & 0,65 & 0,65 \\
\hline EP09 & 0,21 & 0,57 & 0,90 & 0,87 & 0,89 \\
\hline EP14 & 0,11 & 0,51 & 0,85 & 0,88 & 0,93 \\
\hline PREZ05 & 0,35 & 0,65 & 0,87 & 0,86 & 0,86 \\
\hline PREZ10 & 0,14 & 0,53 & 0,87 & 0,89 & 0,94 \\
\hline PREZ15 & 0,04 & 0,44 & 0,79 & 0,83 & 0,90 \\
\hline
\end{tabular}

Zdroj: Vlastní tabulka a výpočty autora.

V zásadě tedy lze říci, že volební podpora Občanské platformy, mezi jejíž hlavní aspekty patři stabilní podpora v největších městech, umírněná územní koncentrace hlasů a poměrně silná vazba mezi výsledky strany v různých arénách, je podobná v regionech nezávisle na jejich historickému dědictví a přiliš se nezměnila, snad s určitou výhradou u Malopolska, za celých čtrnáct let existence subjektu mezi roky 2001-2015.

KAM ZMIZELY HLASY? ZISKY STRANY MODERNÍ V KONTEXTU VOLEBNÍ PODPORY OBČANSKÉ PLATFORMY

Př́ććn propadu Občanské platformy ve volbách 2015, kdy oproti roku 2011 ztratila v celostátním měřítku více ně̌ $15 \%$ hlasů a téměr sedm desítek mandátů v Sejmu, je nepochybně mnoho. Z hlediska zkoumání volební podpory a tématu tohoto textu se jako vhodné nabízí zaměření na vliv nového aktéra na polské politické scéně, kterým se stala strana Moderní. Tento subjekt byl založen na konci května 2015, tedy nedlouho před volbami (Bankier.pl 2015). Přesto dokázala v ř́jnu téhož roku získat 7,6 \% hlasů (PKW 2015). Od počátku deklarovaný liberalismus, a to zejména $\mathrm{v}$ hospodářské oblasti, z Moderních činí potenciálního spojence v parlamentu, ale rovněž konkurenta PO v souboji o voličskou přízeň. Nabízí se tedy logická hypotéza, že část propadu PO v posledních volbách byla způsobena přesunem jejích voličů $\mathrm{k}$ této nové straně. $\mathrm{Na}$ úrovni vojvodství je rozložení podpory obou subjektů podobné (viz Tabulka 18). 
Tabulka 18: Volební výsledky Občanské platformy (2011 a 2015) a Moderních (2015) $\mathrm{\%} \%$

\begin{tabular}{|c|c|c|c|c|}
\hline Vojvodství/strana & PO2011 & PO2015 & M.2015 & PO + M. 2015 \\
\hline Dolnoslezsko & 45,95 & 29,65 & 8,69 & 38,34 \\
\hline Lodžsko & 35,84 & 23,15 & 6,70 & 29,85 \\
\hline Malopolsko & 36,26 & 19,43 & 5,20 & 24,63 \\
\hline
\end{tabular}

Zdroj: Vlastní tabulka dle NSD 2017, PKW 2015.

Nyní bude postup podobný, jako v případě analýzy volebních výsledků LPR a Sebeobrany. Nejprve bude provedena korelační analýza volebních výsledků Moderních v jejich prvních a (prozatím) posledních volbách s ostatními stranami z roku 2011.

Zjištěné výsledky poměrně přesně zapadají do kontextu předchozích korelačních analýz a potvrzují významnou souvislost elektorátů Moderních a Občanské platformy z hlediska prostorového rozložení (viz Tabulka 19).

Tabulka 19: Korelační analýza volebních výsledků Moderních (2015) a ostatních stran (2011) ve zkoumaných vojvodstvích

\begin{tabular}{|c|c|c|c|c|c|}
\hline Vojvodství & Strana & PiS 2011 & PO 2011 & PSL 2011 & SLD 2011 \\
\hline Dolnoslezsko & N. 2015 & $-0,35$ & 0,58 & $-0,41$ & $-0,09$ \\
\hline Lodžsko & N. 2015 & $-0,41$ & 0,80 & $-0,64$ & 0,32 \\
\hline Malopolsko & N. 2015 & $-0,52$ & 0,76 & $-0,41$ & 0,19 \\
\hline
\end{tabular}

Zdroj: Vlastní tabulka a výpočty autora.

Stejně jako v předchozí kapitole bude regresní analýza již zaměřena pouze na vztah voličské podpory dvou stran. Tabulka 20 a hodnoty indexu determinace $v$ ní zapsané ukazují, že zisky PO (nezávislá proměnná) jsou poměrně dobrým indikátorem pro výsledky Moderních (závislá proměnná) o 4 roky později, přesto je mezi regiony velmi výrazný rozdíl - V Dolním Slezsku, kde je PO (i M.) úspěšnější než v ostatních regionech, je index na přibližně poloviční hodnotě.

Tabulka 20: Index determinace regresní analýzy volebních výsledků Občanské platformy (2011) a Moderních (2015)

\begin{tabular}{|c|c|}
\hline Vojvodství & Hodnota indexu \\
\hline Dolnoslezsko & 0,33 \\
\hline Lodžsko & 0,64 \\
\hline Malopolsko & 0,57 \\
\hline
\end{tabular}

Zdroj: Vlastní tabulka a výpočty autora. 
Také další hodnoty potvrzují pozitivní vztah obou elektorátů. Regresní koeficient není prriliš vysoký, což je ovšem pochopitelné vzhledem k velkým rozdílům mezi zisky stran. Ve všech vojvodstvích nicméně platí, že se zvyšujícím se ziskem PO v roce 2011 se $\mathrm{v}$ následujících volbách zvyšoval i podíl hlasů pro M (viz Tabulka 21).

Tabulka 21: Výsledky regresní analýzy vysvětlujících volební podporu Moderních (2015) pomocí volebních výsledků Občanské platformy (2011)

\begin{tabular}{|c|c|c|c|}
\hline Proměnná & Vojvodství & B & Beta \\
\hline \multirow{3}{*}{ Konstanta } & Dolnoslezsko & $-1,65$ & \\
\cline { 2 - 4 } & Lodžsko & 0,33 & \\
\cline { 2 - 4 } & Malopolsko & $-0,83$ & \\
\hline \multirow{3}{*}{ PO 2011 } & Dolnoslezsko & 0,20 & 0,58 \\
\cline { 2 - 4 } & Lodžsko & 0,18 & 0,80 \\
\cline { 2 - 4 } & Malopolsko & 0,18 & 0,76 \\
\hline
\end{tabular}

Zdroj: Vlastní tabulka a výpočty autora.

Jaký je tedy závěr z těchto zjištění? Návaznost výsledků Moderních na Občanskou platformu existuje a je silnější zejména v obou východnějších regionech Polska B (a C). Souboj o podobnou část voličské obce si uvědomuji i oba subjekty, které v současnosti vyjednávají o společné kandidatuře ve volbách do samosprávy, které se uskuteční na podzim 2018.

\section{c. Polská lidová strana}

Tento subjekt, zástupce již téměř neexistující rodiny agrárních stran, je tradičním účastníkem polského politického života. Nedosahuje již sice takových úspěchů, jako tomu bylo v devadesátých letech, přesto však volební podpora prozatím vždy postačila na překonání pětiprocentní klauzule. PSL není tak jednoznačně spojena jen s jednou geografických částí země, jako je tomu u PiS či PO, je tedy otázkou, zda se to nějak projeví ve sledovaných parametrech.

Mapa 10 zobrazuje nadprůměrnou podporu má strana $\mathrm{v}$ obcích po celém dolnoslezském regionu, zpravidla jde o samosprávy venkovského charakteru. Neúspěšná je mj. v hlavním městě Wrocławi a v některých dalších větších městech. 
Mapa 10: Území stabilní volební podpory a nepodpory PSL v Dolnoslezském vojvodství

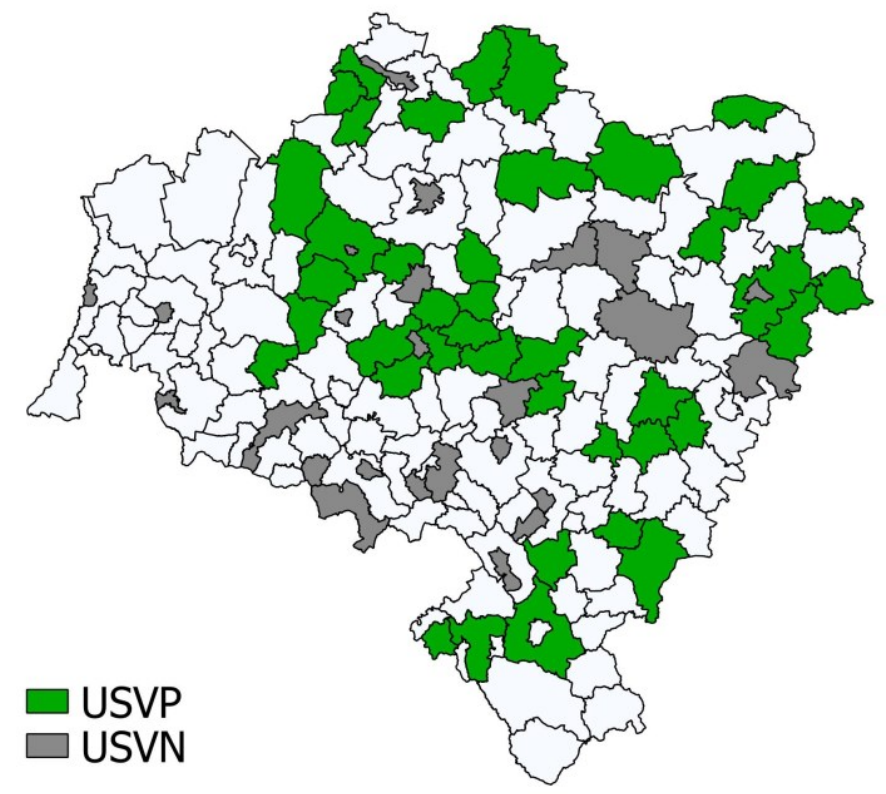

Zdroj: Vlastní mapa autora.

Podobná pestrost panuje také v dalším zkoumaném vojvodství. Zaujme kontrast oproti mapě vyznačující podporu Občanské platformy, což ovšem již naznačovala data zabývající se korelací. Nadprůměrné zisky $\mathrm{v}$ obcích na severovýchodě a jihozápadě jsou doprovázeny slabými výsledky v Lodži a jejím okolí (viz Mapa 11). 
Mapa 11: Území stabilní volební podpory a nepodpory PSL v Lodžském vojvodství

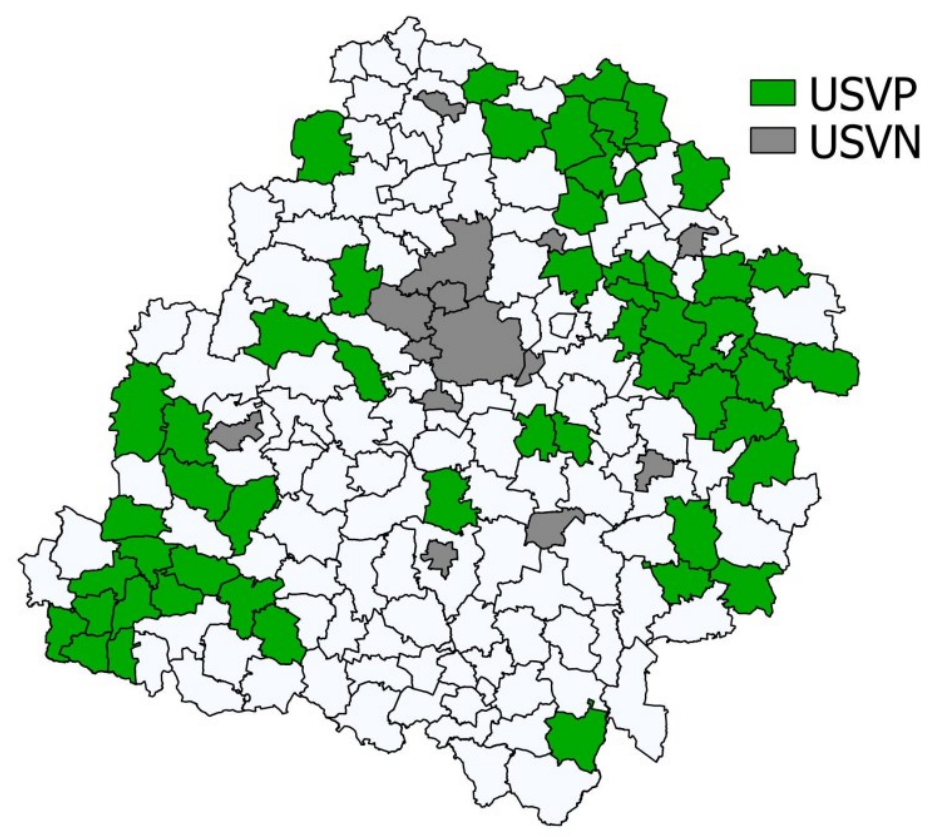

Zdroj: Vlastní mapa autora.

A ani Malopolsko významně nevybočuje ze zjištěných poznatků. Zajímavý je zelený pás na severu regionu, který sousedí se Svatokřrižským vojvodstvím, což je pro PSL vůbec nejúspěšnější region. Výrazně méně se straně daří v Krakově a západně od něj (viz Mapa 12). 
Mapa 12: Území stabilní volební podpory a nepodpory PSL $\mathbf{v}$ Malopolském vojvodství

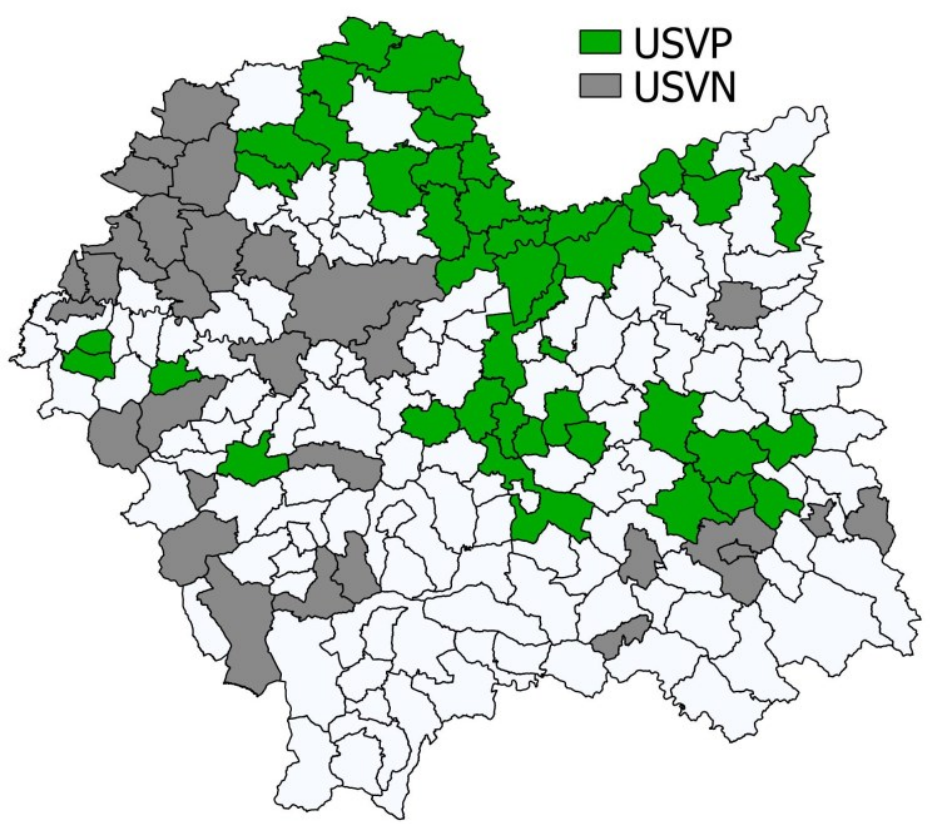

Zdroj: Vlastní mapa autora.

U Polské lidové strany lze poprvé zaznamenat paradox, který může přinášet použití dvou podobně zaměřených metod na zjištění míry koncentrace, avšak pracující s odlišným typem dat. Extrémně vysokých hodnot dosahuje v některých př́padech variační koeficient, Giniho koeficient naopak vykazuje poměrně nevysoká čísla. Z logiky výpočtu vyplývá, že procentuálně nízký výsledek, kterého strana dosahuje ve velkých městech, způsobuje dojem koncentrace u první metody. Jelikož je však díky velikosti takových obcí relativně nízkých čísel dosahováno pomocí velkého množství hlasů v absolutních číslech, hodnota Giniho koeficientu, který s nimi počítá, zůstává nízká. Na tomto př́kladu se ukazuje vhodnost užití různých koeficientů, přítomnost pouze jednoho z nich by mohla přinést nesprávnou intepretaci. Mimo Lodžského vojvodství zůstávají ovšem hodnoty, jako tomu bylo u předchozích subjektů, velmi podobné (viz Tabulka 22). 
Tabulka 22: Hodnoty variačního a Giniho koeficientu pro PSL ve volbách 20012015

\begin{tabular}{|c|c|c|c|c|c|c|c|c|c|c|}
\hline Volby & \multicolumn{2}{|c}{2001} & \multicolumn{2}{c|}{2005} & \multicolumn{2}{c|}{2007} & \multicolumn{2}{c|}{2011} & \multicolumn{2}{c|}{2015} \\
\hline & VAR & GINI & VAR & GINI & VAR & GINI & VAR & GINI & VAR & GINI \\
\hline Dolnoslezsko & 0,65 & 0,26 & 0,87 & 0,30 & 0,63 & 0,25 & 0,66 & 0,26 & 0,80 & 0,28 \\
\hline Lodžsko & 0,55 & 0,30 & 0,64 & 0,31 & 0,51 & 0,24 & 0,51 & 0,28 & 0,56 & 0,25 \\
\hline Malopolsko & 0,73 & 0,33 & 1,05 & 0,38 & 0,71 & 0,29 & 0,84 & 0,30 & 1,01 & 0,33 \\
\hline
\end{tabular}

Zdroj: Vlastní tabulka a výpočty autora.

U hodnot korelačního koeficientu je viditelné, že jde o tradiční subjekt, který má poměrně stabilní oblasti volební podpory v různých arénách, byt' v Dolním Slezsku nikde nedosahuje extrémních hodnot. Trochu překvapivé je to u prezidentských voleb, nebot' zde kandidáti strany získávají významně menší podporu, než v parlamentních a evropských volbách. Souvislost je ovšem stále poměrně silná (viz Tabulka 23).

Tabulka 23: Korelační analýza volebních výsledků PSL v Dolnoslezském vojvodství v letech 2001-2015 (S = volby do Sejmu, šedá výpln̆ = hodnoty nad 0,90 vč., $N=169$ )

\begin{tabular}{|c|c|c|c|c|c|}
\hline Volby & S2001 & S2005 & S2007 & S2011 & S2015 \\
\hline EP04 & 0,77 & 0,66 & 0,64 & 0,49 & 0,59 \\
\hline EP09 & 0,54 & 0,58 & 0,78 & 0,71 & 0,58 \\
\hline EP14 & 0,60 & 0,50 & 0,65 & 0,62 & 0,76 \\
\hline PREZ05 & 0,69 & 0,58 & 0,69 & 0,61 & 0,62 \\
\hline PREZ10 & 0,70 & 0,60 & 0,74 & 0,76 & 0,66 \\
\hline PREZ15 & 0,57 & 0,55 & 0,70 & 0,58 & 0,72 \\
\hline
\end{tabular}

Zdroj: Vlastní tabulka a výpočty autora.

Tabulka 24 dokazuje, že výše zmíněné platí ještě ve větší míře pro Lodž a její okolí, i zde je souvztažnost tradiční, silná a kontinuální např́íc celým patnáctiletým obdobím. 
Tabulka 24: Korelační analýza volebních výsledků PSL v Lodžském vojvodství v letech 2001-2015 $(\mathrm{S}=$ volby do Sejmu, šedá výpln̆ = hodnoty nad 0,90 vč. $\mathrm{N}=$ 177)

\begin{tabular}{|c|c|c|c|c|c|}
\hline Volby & S2001 & S2005 & S2007 & S2011 & S2015 \\
\hline EP04 & 0,79 & 0,65 & 0,69 & 0,71 & 0,64 \\
\hline EP09 & 0,72 & 0,75 & 0,73 & 0,79 & 0,73 \\
\hline EP14 & 0,70 & 0,73 & 0,75 & 0,85 & 0,80 \\
\hline PREZ05 & 0,85 & 0,74 & 0,79 & 0,82 & 0,75 \\
\hline PREZ10 & 0,74 & 0,62 & 0,74 & 0,77 & 0,69 \\
\hline PREZ15 & 0,73 & 0,59 & 0,79 & 0,83 & 0,79 \\
\hline
\end{tabular}

Zdroj: Vlastní tabulka a výpočty autora.

Největší je stabilita výsledků Polské strany lidové v obcích a různých volbách v Malopolsku, kde se straně, jak již bylo ukázáno, př́liš nedaří. Zejména v posledních volbách, kdy se stran dostala do Sejmu jen těsně, ukazují hodnoty velmi vysokou souvztažnost (viz Tabulka 25).

Tabulka 25: Korelační analýza volebních výsledků PSL v Malopolském vojvodství v letech 2001-2015 ( $\mathrm{S}=$ volby do Sejmu, šedá výplň = hodnoty nad 0,90 vč., $\mathrm{N}=$ 182)

\begin{tabular}{|c|c|c|c|c|c|}
\hline Volby & S2001 & S2005 & S2007 & S2011 & S2015 \\
\hline EP04 & 0,64 & 0,61 & 0,62 & 0,65 & 0,66 \\
\hline EP09 & 0,75 & 0,73 & 0,83 & 0,79 & 0,83 \\
\hline EP14 & 0,74 & 0,72 & 0,81 & 0,84 & 0,89 \\
\hline PREZ05 & 0,80 & 0,72 & 0,76 & 0,78 & 0,86 \\
\hline PREZ10 & 0,75 & 0,66 & 0,77 & 0,84 & 0,89 \\
\hline PREZ15 & 0,72 & 0,64 & 0,69 & 0,77 & 0,87 \\
\hline
\end{tabular}

Zdroj: Vlastní tabulka a výpočty autora.

Polská lidová strana je tedy poměrně jednoznačně úspěšná v menších sídlech, $\mathrm{v}$ nichž se může spolehnout na poměrně pravidelnou podporu značné části z nich. To je vzhledem k ideové profilaci subjektu poměrně logické, stejně jako velmi malá úspěšnost ve městech. Tento profil, odlišný od většiny ostatních stran, jí spolu s dlouhou historií a disciplinovanými voliči vytváří situaci, kdy jsou volební výsledky většinou podobně strukturovány. Tato tvrzení platí v podstatě stejnou měrou pro všechny tři zkoumaná vojvodství. 


\section{d. Svaz demokratické levice}

Tento levicový subjekt prošel v uplynulé půldruhé dekádě významnou transformací a snížením relevance - z klíčového aktéra polského stranického systému se v průběhu let 2001-2005 propadl do pozice menší strany, která navíc trvale působila v opozici. Tento stav byl víceméně nezávislý na tom, zda SLD kandidoval samostatně, či jako hlavní součást širšího spojenectví (středo)levicových sil. Tyto dva faktory (výrazný propad podpory a různé formy kandidatury) by teoreticky mohly mít vliv na prostorové rozložení podpory.

V Dolním Slezsku je navzdory výše řečenému poměrně velké množství gmin, ve kterých má tento subjekt jasnou pozici (at' již dobrou či spíše slabši). Volební bašty jsou př́tomny v západní polovině regionu, na východě a ve Wrocławi se Svazu dlouhodobě prŕliš nedaří (viz Mapa 13).

\section{Mapa 13: Území stabilní volební podpory a nepodpory SLD v Dolnoslezském} vojvodství

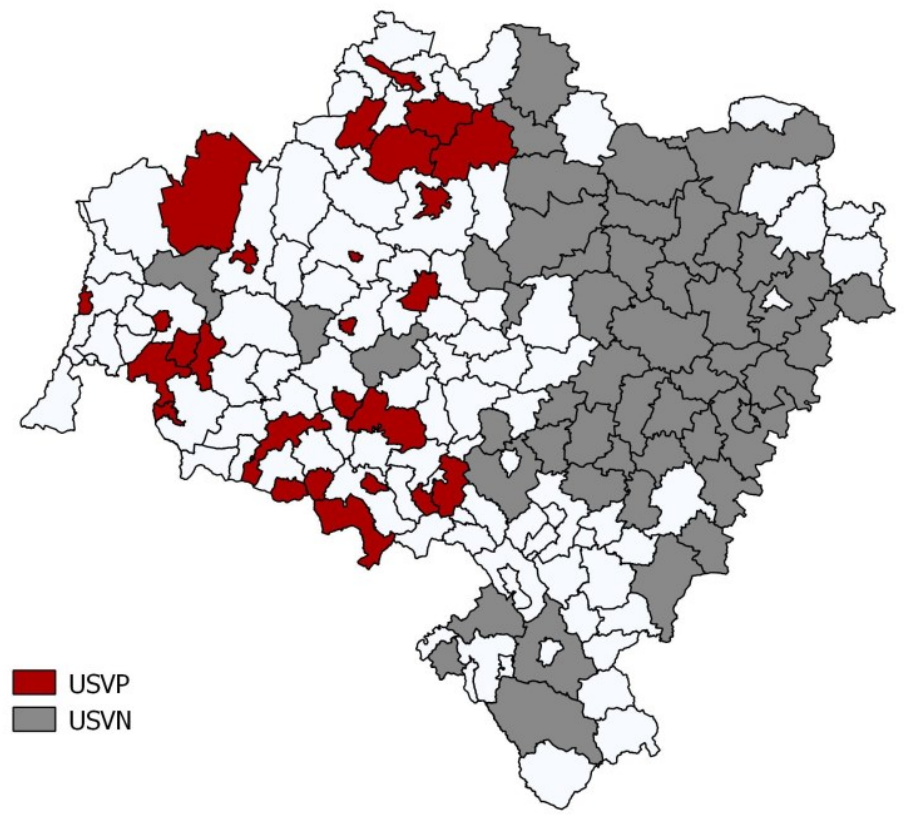

Zdroj: Vlastní mapa autora.

V Lodžském vojvodství je na tom strana v podstatě totožně, jako Občanská platforma - pravidelně se jí daří v hlavním městě regionu, jinde jsou výsledky nejednoznačné či dlouhodobě slabší, což platí i pro okolí Lodže (viz Mapa 14). 
Mapa 14: Území stabilní volební podpory a nepodpory SLD v Lodžském vojvodství

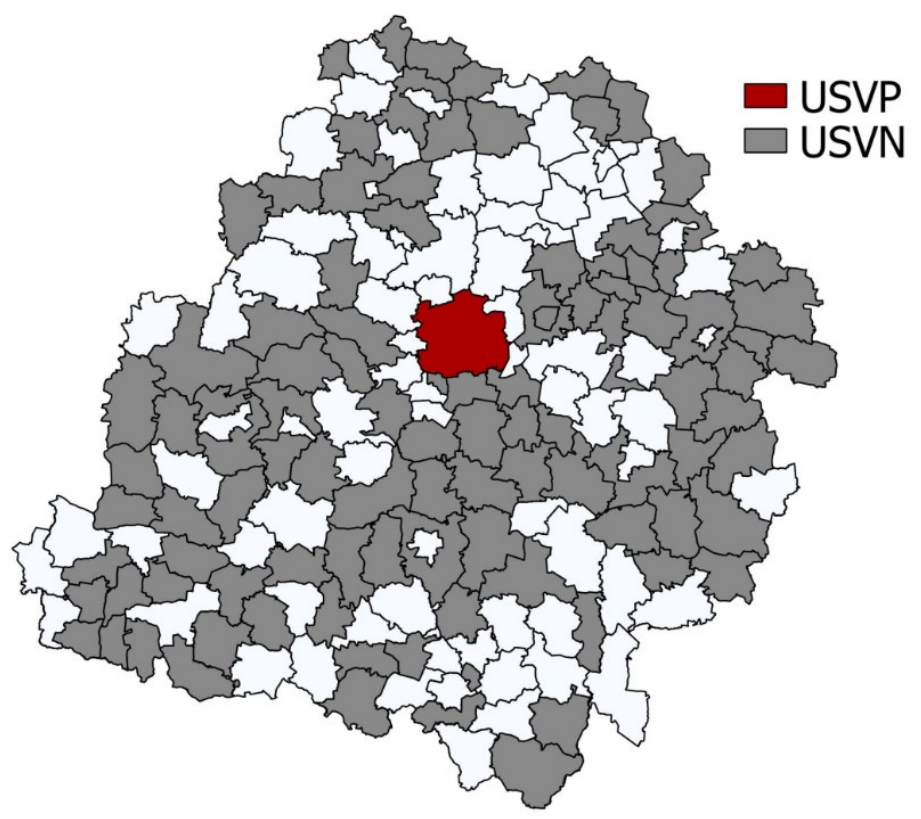

Zdroj: Vlastní mapa autora.

Mapa 15 ukazující situaci v Malopolsku nabízí opět odlišný obrázek volební podpory - významnou podporu má Svaz na západě u hranic se Slezským vojvodstvím, většina obcí je ovšem pro subjekt tradičně nepř́liš úspěšná, což se netýká Krakova. U SLD lze tedy vidět největší rozdíly ze zkoumaných subjektů z hlediska stability volební podpory, $v$ každém regionu je situace odlišná. Zajímavá je př́tomnost mnoha jednoznačně úspěšných oblastí, přestože došlo k již zmíněnému výraznému propadu ve volební podpoře. U PiS či PO, jejichž podpora naopak podobně zásadně stoupla, se podobně dlouhodobě vyhraněné oblasti nalézt téměř nepodařilo. 
Mapa 15: Území stabilní volební podpory a nepodpory SLD $v$ Malopolském vojvodství

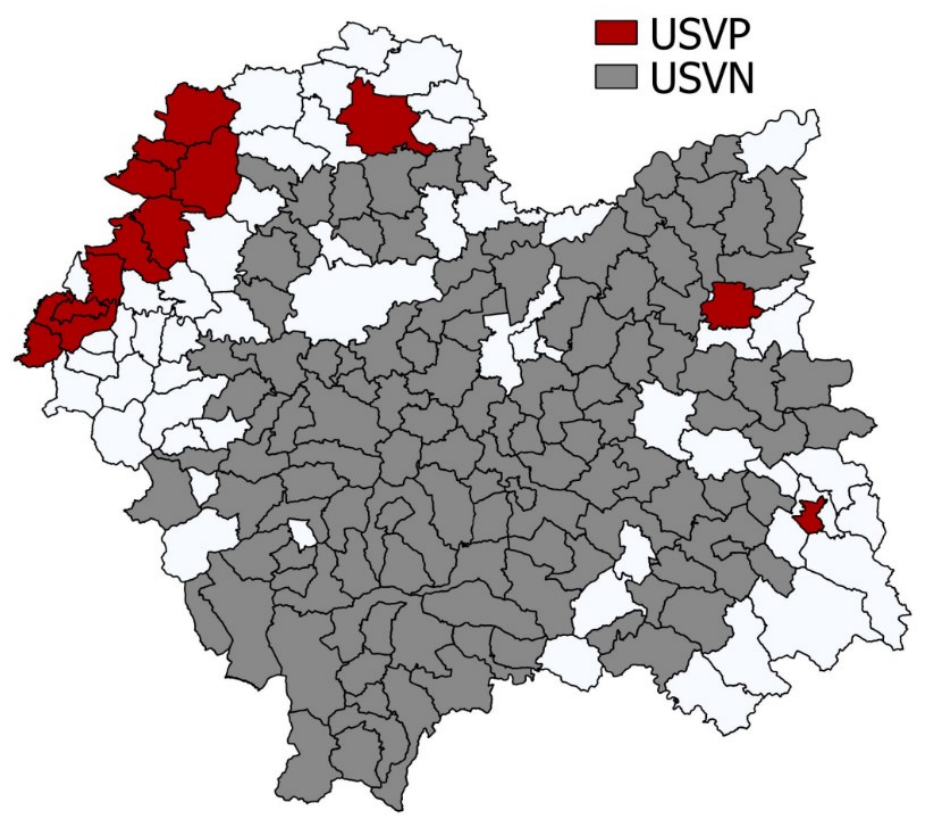

Zdroj: Vlastní mapa autora.

SLD vykazuje velké rozdíly i v případě prostorového rozložení volební podpory. U Malopolska odpovídá interpretace hodnot obou koeficientů zjištěním, která byla zmíněna u PSL - nízká procentuální podpora ve větších gminách. Dolnoslezský a Lodžský region jsou strukturovány opačným zpơsobem, byt' ne natolik výrazně - větší obce (zejména ve druhém ze zmiňovaných případů) jsou pro obec zdrojem jak procentuálně, tak absolutně vyšších zisků (viz Tabulka 26). SLD má tedy regionálně nejrozmanitější podporu, což již bylo naznačeno kartografickým způsobem zobrazení volební podpory.

Tabulka 26: Hodnoty variačního a Giniho koeficientu pro SLD ve volbách 20012015

\begin{tabular}{|c|c|c|c|c|c|c|c|c|c|c|}
\hline Volby & \multicolumn{2}{|c|}{2001} & \multicolumn{2}{c|}{2005} & \multicolumn{2}{c|}{2007} & \multicolumn{2}{c|}{2011} & \multicolumn{2}{c|}{2015} \\
\hline & VAR & GINI & VAR & GINI & VAR & GINI & VAR & GINI & VAR & GINI \\
\hline Dolnoslezsko & 0,18 & 0,33 & 0,39 & 0,49 & 0,30 & 0,37 & 0,40 & 0,32 & 0,33 & 0,39 \\
\hline Lodžsko & 0,32 & 0,53 & 0,60 & 0,63 & 0,41 & 0,61 & 0,37 & 0,56 & 0,43 & 0,58 \\
\hline Malopolsko & 0,49 & 0,19 & 0,87 & 0,15 & 0,62 & 0,17 & 0,61 & 0,22 & 0,70 & 0,13 \\
\hline
\end{tabular}

Zdroj: Vlastní tabulka a výpočty autora. 
U SLD, popř. jejich koalic je měření korelace mezi volebními výsledky omezeno pouze na dvoje prezidentské volby ${ }^{12}$. Voleb do evropského parlamentu se strana zúčastnila, stejně jako ostatní subjekty, celkem třikrát.

Přes toto omezení poskytuje analýza určitou představu o souvislosti volebních výsledků. Vztah mezi výsledky je v Dolním Slezsku ve většině případů podstatný, byt' nedosahuje extrémně vysokých hodnot. Nelze ani vysledovat vzorec změn, který by byl způsoben samostatnou či naopak koaliční kandidaturou ve sněmovních volbách (viz Tabulka 27).

Tabulka 27: Korelační analýza volebních výsledků SLD v Dolnoslezském vojvodství v letech 2001-2015 (S = volby do Sejmu, šedá výplň $=$ hodnoty nad 0,90 vč., $\mathbf{N}=169$ )

\begin{tabular}{|c|c|c|c|c|c|}
\hline Volby & S2001 & S2005 & S2007 & S2011 & S2015 \\
\hline EP04 & 0,51 & 0,56 & 0,46 & 0,30 & 0,43 \\
\hline EP09 & 0,49 & 0,50 & 0,49 & 0,25 & 0,56 \\
\hline EP14 & 0,60 & 0,51 & 0,51 & 0,39 & 0,59 \\
\hline PREZ10 & 0,43 & 0,26 & 0,48 & 0,52 & 0,40 \\
\hline PREZ15 & 0,42 & 0,28 & 0,36 & 0,27 & 0,47 \\
\hline
\end{tabular}

Zdroj: Vlastní tabulka a výpočty autora.

Totéž můžeme říct o výsledcích SLD v Lodži. Tabulka 28 dokládá, že ztráta dvou třetin hlasů mezi roky 2001 a 2005 se na změně struktury podpory strany př́liš neprojevil a oslabování, ke kterému obvykle vlivem času logicky dochází, je zde poměrně slabé.

Tabulka 28: Korelační analýza volebních výsledků SLD v Lodžském vojvodství v letech 2001-2015 (S = volby do Sejmu, šedá výplň = hodnoty nad 0,90 vč., $N=$ 177)

\begin{tabular}{|c|c|c|c|c|c|}
\hline Volby & S2001 & S2005 & S2007 & S2011 & S2015 \\
\hline EP04 & 0,67 & 0,57 & 0,64 & 0,48 & 0,48 \\
\hline EP09 & 0,73 & 0,67 & 0,62 & 0,55 & 0,55 \\
\hline EP14 & 0,65 & 0,54 & 0,58 & 0,59 & 0,56 \\
\hline PREZ10 & 0,62 & 0,43 & 0,49 & 0,48 & 0,39 \\
\hline PREZ15 & 0,17 & 0,36 & 0,18 & 0,39 & 0,43 \\
\hline
\end{tabular}

Zdroj: Vlastní tabulka a výpočty autora.

12 Kandidát strany v roce 2005, Włodzimierz Cimoszewicz, necelé dva měsíce před volbami odstoupil kvůli tzv. kauze Orlen. 
Nejvyšších hodnot ovšem dosahuje koeficient v Malopolsku, v některých př́padech je shoda téměř perfektní, zejména u posledních voleb do Sejmu. Zde je také př́tomen, byt' v poměrně malé míre, všeobecný trend oslabování souvislosti mezi výsledky ve volbách 2005 a 2011 s prezidentskými a evropskými volbami (viz Tabulka 29), což je poněkud paradoxní, nebot' v těchto všech volbách SLD kandidovala samostatně, což by na první pohled mělo souvislost spíše posilovat.

Tabulka 29: Korelační analýza volebních výsledků SLD v Malopolském vojvodství v letech 2001-2015 (S = volby do Sejmu, šedá výplň = hodnoty nad 0,90 vč.)

\begin{tabular}{|c|c|c|c|c|c|}
\hline Volby & S2001 & S2005 & S2007 & S2011 & S2015 \\
\hline EP04 & 0,85 & 0,74 & 0,88 & 0,80 & 0,83 \\
\hline EP09 & 0,90 & 0,76 & 0,94 & 0,78 & 0,91 \\
\hline EP14 & 0,87 & 0,75 & 0,90 & 0,82 & 0,94 \\
\hline PREZ10 & 0,79 & 0,59 & 0,79 & 0,78 & 0,82 \\
\hline PREZ15 & 0,69 & 0,62 & 0,74 & 0,72 & 0,72 \\
\hline
\end{tabular}

Zdroj: Vlastní tabulka a výpočty autora.

SLD vykazuje ze zkoumaných subjektů největší rozdíly v různých aspektech prostorové analýzy volební podpory. Snad jen míra souvislosti v různých volebních arénách vykazuje poměrně určitou míru shody (byt' ani zde ne takovou, jako u PSL či PO), jinak ovšem o podpoře strany na základě zvolených metod nelze říci v podstatě žádná generalizující tvrzení. Naopak rozdílné formy kandidatury nejsou přícinou jednoznačného trendu.

\section{Závěr}

Jaké jsou tedy hlavní zjištěné poznatky? Ze studie je zřejmé, že relativní stabilita polského stranického systému $\mathrm{v}$ tomto tisíciletí se projevila i z hlediska volební geografie, kde lze u většiny zkoumaných jevi̊ hovořit o dlouhodobých trendech se spíše menším počtem zásadních změn. Je nutno vzít v potaz, že tento text byl založen na výsledcích pouze ze tří vojvodství z celkových šestnácti, a situace v každém regionu je pochopitelně ovlivňována i dalšími vlivy např. lokálního charakteru. Analýza Dolnoslezského, Lodžského a Malopolského vojvodství jakožto nejpodobnějších ze všech regionů ovšem nepochybně umožňuje vyslovit určité závěry, týkající se volební geografie a prostorového rozložení podpory.

Z hlediska porovnání prostorové analýzy voleb jednotlivých vojvodství je poměrně jednoznačně vidět trend u vzájemné souvislosti volebních výsledků. Vojvodství Lodžské a Malopolské dlouhodobě vykazují větší souvislost volebních výsledků, než je tomu $\mathrm{v}$ Dolnoslezském regionu. $\mathrm{V}$ menší míře je toto tvrzení platné i pro hledání souvislostí mezi jednotlivými výsledky jednoho subjektu, kde zejména u PO a PiS existují výjimky. 
Jako poměrně přirozené vysvětlení tohoto jevu se nabízí právě historický vývoj, nebot' $\mathrm{v}$ Dolnoslezském vojvodství proběhla po druhé světové válce kompletní výměna obyvatelstva $\mathrm{v}$ důsledku exodu původního německého osídlení na západ (podrobněji Řezník 2002: 193, Davies 2003: 28-29, 96), jejich místo zaujali nově př́chozí Poláci z východu, zejména z oblasti ukrajinského Lvova (Paczkowski 2000: 92). Vliv těchto faktorů bývá obecně dlouhodobý, což je výrazně vidět i např́klad v České republice v „sudetských“ oblastech, které z politického hlediska stále vykazují odlišnosti od zbytku země, např. v síle pozice KSČM či nižší volební účasti (což je ostatně i případ Dolnoslezského vojvodství, kde je podíl občanů hlasujících ve volbách do dolní komory dlouhodobě podprůměrný, viz př́lohy, Tabulka 34). Je nicméně zajímavé, že zatímco v Polsku jsou tyto prribližně sedm desítek let osídlené oblasti zdrojem podpory pro Občanskou platformu coby stranu liberálně-konzervativní a jednoznačně proevropsky zaměřenou (Platforma Obywatelska 2016: 18-19), v př́padě České republiky jde naopak o regiony, kde se daří opačně orientovaným subjektům (dlouhodobě komunisté, v současnosti také SPD). Tato odlišnost by nepochybně mohla být východiskem pro výzkum odlišností voličského chování $\mathrm{v}$ regionech s poválečným dosídlením.

Největší zlom ve vývoji polského stranického systému ve sledovaném období do roku 2015 prrišel ve volbách roku 2007. Významné posílení dvou hlavních subjektů a (dočasné) redukce počtu stranických aktérů na čtyři byly doprovázeny také asi největšími změnami z hlediska prostorového rozložení podpory. O Právu a spravedlnosti, nejmarkantnějším př́padě změny profilu voličů strany z územního hlediska, již byla řeč. Strana mezi těmito volbami sice př́liš neposílila $\mathrm{z}$ hlediska podílu hlasů, to je však třeba vidět $\mathrm{v}$ kontextu výrazného nárůstu volební účasti mezi roky 2005 a 2007, jak je popsáno v Tabulce 34. V absolutních počtech hlasů strana posílila o více než polovinu, na čemž měli významný podíl bývalí voliči Sebeobrany a (zejména) LPR. I díky tomu si PiS i př́i porážkách na celostátní úrovni v letech 2007 a 2011 udržel v Malopolsku vedoucí pozici a v posledních volbách se stal nezpochybnitelným hegemonem tohoto regionu (kterým je i ve zbylé části „Polska C“, Podkarpatském vojvodství). Přestože v roce 2015 strana překročila pomyslnou linii oddělující Polsko A od Polska B a C a premiérově zvítězila mj. v oblasti Dolního Slezska, bývalý ruský, a především rakouský zábor, jádro podpory bývalé Solidarity (Dudek 2013: 42), je pro stranu stále tím místem, kde je její síla nejvyšší.

$\mathrm{Z}$ výše popsaných důvodů byl právě straně Jaroslawa Kaczyńského věnován $\mathrm{v}$ textu největší prostor, díky čemuž je možno mít o volební podpoře a jejích souvislostech s dalšími faktory poměrně ucelenou představu.

Celkově je patrné, že si strany (s částečnou výjimkou SLD) na regionální úrovni drží podobnou strukturu svých voličských bank. Na otázku, zda vývoj prostorového rozložení volební podpory hlavních stran kopíroval ve stabilizaci 
vývoj samotného stranického systému, lze tedy (nejpozději od roku 2007) odpovědět kladně.

Je rovněž evidentní, že i strany s velmi odlišnými zdroji volební podpory spolu dokáží účinně kooperovat (již zmiňovaný př́pad PO a PSL) a tento fakt tedy není sám o sobě př́liš určující pro interakce ve stranickém systému, byt' nepochybně hraje podstatnou roli $\mathrm{v}$ programech stran a při prípadném vyjednávání o spolupráci na vládní úrovni.

$\mathrm{V}$ př́ípadě dvou nejsilnějších subjektů, PiS a PO, ovšem obrat směrem $\mathrm{k}$ výrazné odlišnosti voličských obcí proběhl v období zostřujícího se vztahu těchto konkurentů, které spojuje pravicová profilace, podobný čas vzniku a „postsolidaritní“ tábor, ze kterého obě strany vzešly. Osobní animozity, programové rozdíly a ideový rozkol způsobily vznik rivality (a později vyloženého nepřátelství), který byl již v roce 2005 popisován prímými aktéry jako souboj Polska solidárního s Polskem liberálním (Šaradín, Bradová et al. 2007: 73). Historik a bývalý mluvčí hnutí Solidarita Karol Modzelewski hovoři ve své biografii o tom, že se Polsko potýká „...s přerušením společenských vazeb a rozbitím polské společnosti na dvě části, které jsou si navzájem cizí, a dokonce nepřátelské..." (Modzelewski 2015: 329-330). Pokud by toto konstatování bylo vztaženo pouze na souboj dvou hlavních polských stran, je možno říci, že studie přináší výsledky, které je z pohledu kvantitativních metod doplňují. Fakt, že výrazné rozdíly neexistují pouze na (všeobecně známé) linii západ-východ, ale i v jednotlivých vojvodstvích, je bezesporu také vhodným námětem pro další práce věnující se specifické situaci v konkrétních regionech, a to nejen $\mathrm{z}$ pohledu volební geografie.

Pokračování trendů vyplývajících z tohoto textu se prozatím jeví jako pravděpodobné, nebot' ani po necelých třech letech u vlády podpora vládnoucího Práva a spravedlnosti zůstává vysoký, což v jejím př́padě nahrává předpokladu o kontinuitě se stavem $\mathrm{z}$ posledního volebního měření sil. Změnu by mohla způsobit strategie dalších politických subjektů, zda přistoupí k (částečné) integraci se snahou vytvořit konkurenceschopnou alternativu pro další volby, které by měly proběhnout na podzim 2019, nebo zda budou postupovat samostatně. V prvním př́padě by kromě výhody při přepočtu hlasů na mandáty dané poměrně disproporčním volebním systémem mohlo dojít ke změně dosavadních vzorců volební podpory.

At' už se rozhodnou jakkoli, př́padná porážka vládnoucího Práva a spravedlnosti nemusí znamenat snížení napětí v polské politice, ale naopak její další posílení. Dlouhodobý výzkum prostorového rozložení zisků voličských hlasů polských stran je jednou z možností, jak tento jev $\mathrm{v}$ rámci kvantitativního výzkumu dobře pozorovat. 


\section{Literatura a prameny}

Balík, Stanislav a Vlastimil Havlík (eds.) (2011): Koalični vládnutí ve strední Evropě: (19902010). Brno: Mezinárodní politologický ústav.

Bankier.pl (2015): „NowoczesnaPL: uwolnić gospodarkę, zmienić system ubezpieczeń

Społecznych“, online (http://www.bankier.pl/wiadomosc/NowoczesnaPL-uwolnicgospodarke-zmienic-systemubezpieczen-spolecznych-3352426.html).

Barwiński, Marek (2006): „Influence of Former Political Borders on Election Results in Poland.“ Online (http://web.unitn.it/archive/events/borderscapes/download/ abstract/barwinski_paper.pdf).

Barwiński, Marek (2015): Geografia historyczna i polityczna w badaniach Marka Kotera. Lódź: Wydawnictwo Uniwersytetu Łódzkiego.

Breindl, Jan (2003): „Sebeobrana a Liga polských rodin - protestní strany v polském parlamentu." Stredoevropské politické studie 5(4), online (https://journals.muni.cz/cepsr/article/view/4025/5307).

CODGIK (2017). „1. zbiory danych państwowego rejestru granic i powierzchni jednostek podziałów terytorialnych kraju." Centralny Ośrodek Dokumentacji Geodezyjnej i Kartograficznej - CODGiK, online (http://www.codgik.gov.pl/index.php/darmowe-dane/prg.html).

Cabada, Ladislav (2013): Strany jednoho tématu ve strední Evropè. Brno: Václav Klemm.

Davies, Norman (2003): Polsko: dějiny národa ve strédní Evropě. Praha: Prostor.

De Vaus, David (2002): Analyzing social science data. Thousand Oaks, Calif.: SAGE.

Dudek, Antoni (2013): Historia polityczna Polski 1989-2012. Kraków: Wydawnictwo Znak.

Fiala, Petr a Ryszard Herbut (eds.) (2003): Stredoevropské systémy politických stran: Céská republika, Mad’arsko, Polsko a Slovensko. Brno: Mezinárodní politologický ústav.

Forward (2010): „Poland's Radio Maryja Known For Its Bigotry, and Its Influence“, online (https://forward.com/news/125079/poland-s-radio-maryja-known-for-itsbigotry-and/).

GUS (2015): „Podstawowe informacje o rozwoju demograficznym Polski do 2014 roku.“, online (http://stat.gov.pl/files/gfx/portalinformacyjny/pl/defaultaktualnosci/5468/ 12/5/1/podstawowe_informacje_o_rozwoju_demograficznym_polski_do_2014.pdf).

GUS (2017a): „Nomenklatura NTS.“ Gtówny Urzqd Statystyczny: online (https://stat.gov.pl/statystyka-regionalna/jednostki-terytorialne/system-

kts/nomenklatura-nts/).

GUS (2017b): „Powierzchnia według województw.“ Główny Urzqad Statystyczny: online (https://stat.gov.pl/statystyka-regionalna/rankingi-statystyczne/powierzchnia-wedlugwojewodztw/).

GUS (2017c): „Ludność według województw.“ Główny Urzqd Statystyczny: online (http://stat.gov.pl/statystyka-regionalna/rankingi-statystyczne/ludnosc-wedlugwojewodztw/).

GUS (2017d): „Registered unemployment rate.“ Główny Urzad Statystyczny: online (https://bdl.stat.gov.pl/BDL/metadane/cechy/2392?back=True).

GUS (2017e): „Gross domestic product per capita.“ Gtówny Urzqd Statystyczny: online (https://bdl.stat.gov.pl/BDL/metadane/cechy/3501?back=True).

Hendl, Jan (2009): Prébled statistických metod: analýza a metaanalýza dat. Praha: Portál.

Hloušek, Vít a Lubomír Kopeček (2010): Politické strany: puivod, ideologie a transformace politických stran v západni a strední Evropè. Praha: Grada. 
Chwalba, Andrzej (2009): Polsko 1989-2008: déjiny současnosti. Brno: Centrum pro studium demokracie a kultury.

Jańczak, Jarosław (2015): „Phantom borders and electoral behaviour in Poland. Historical legacies, political culture and their influence on contemporary politics." Erdkunde 69(2): 125-137. DOI: 10.3112/erdkunde.2015.02.03

Jehlička, Petr a Luděk Sýkora (1991): „Stabilita regionální podpory tradičních politických stran v českých zemích (1920-1990). “ Sborník Ceské geografické společnosti. 1991(2)“ 81-95.

Kabeláčová, Pavla (2014): Vzorce volebního chování ve Zlinském kraji. Brno: Diplomová práce.

Masarykova univerzita.

Kopeček, Lubomír (2004): „Konfliktní linie polské společnosti a politiky v éře transformace." Mezinárodni politika 28 (6): 4-6.

Koubek, Jiří (2007): „Analýza polských parlamentních voleb 2007 a jejich konsekvencí pro stranický systém" Clovék 2(9): online (http://clovek.ff.cuni.cz/ view.php?cisloclanku=2008121601\#4).

Koubek, Jiří (2016): Polský stranický systém 1989-2016: ve żnamení polarizace. Praha: Dizertační práce. Univerzita Karlova.

KSNG (2015): „Podzial administracyjny Polski.“, online (http://ksng.gugik.gov.pl/pliki/ podzial_administracyjny_polski_2015.pdf).

Kowalski, Mariusz (2000): „Geografia wyborcza Polski - przestrzenne zróżnicowanie zachowań wyborczych Polaków w latach 1989-1998.“ Warsqawa: IGiPZ PAN: online (http://rcin.org.pl/igipz/dlibra/docmetadata?id=30322\&from=publication).

Kowalski, Mariusz (2014): „Czy Wielkopolska była prawicowa? Przestrzenne zróżnicowanie zachowań wyborczych w Polsce w latach dwudziestych XX wieku." Prace i Studia Geograficzne 2014(54), 89-105.

Kowalski, Mariusz (2015): „Przestrzenne zróżnicowanie wyników wyborów do Sejmu z 1957 roku." Acta Universitatis Lodriensis Folia Geographica Socio-Oeconomica 2015(21): 73-84.

Kubát, Michal (2005): Demokracie v Polsku: politický systém Polské republiky (1989-2005).

Praha: Slon. Politické systémy.

Kubát, Michal (2006): Vývoj a promèny státního rřrzeni Polska ve 20. století institucionálně politická studie. Praha: Dokořán. Bod (Dokořán).

Modzelewski, Karol (2015): Zaženem dějin klisny!: yyz̧náni potlučeného jezdce. Ostrava: Občanské sdružení PANT. Moderní dějiny (Občanské sdružení PANT).

NSD (2017): „Poland.“ NSD - Norwegian Centre for Research Data: European Election Database: online (http://www.nsd.uib.no/european_election_database/about/).

Paczkowski, Andrzej (2000): Puil stoleti Polska: 1939-1989. Praha: Academia.

Pink, Michal (2012): Volebni mapy Ceské a Slovenské republiky po roce 1993: vzorce, trendy, promèny. Brno: Centrum pro studium demokracie a kultury (CDK).

PKW (2015): „Wyniki wyborów do Sejmu RP.“ Państwowa Komisja Wyborcza: online (http://parlament2015.pkw.gov.pl/349_Wyniki_Sejm).

Platforma Obywatelska (2017): „Deklaracja programowa Platformy Obywatelskiej \#PolskaObywatelska 2.0“ Platforma Obywatelska: online (http://www.platforma.org/ aktualnosc/45494/deklaracja-programowa-platformy-obywatelskiej-polskaobywatelska$2-0)$.

QGIS (2017): A Free and Open Source Geographic Information System: online (http://www.qgis.org/en/site/).

Řezník, Miloš (2002): Polsko. Praha: Libri. Stručná historie států. 
Sokol, Petr (2014): Volebni geografie postkomunistických zemi stredni a východni Evropy. Praha: Disertační práce. Univerzita Karlova.

Stenzelová, Michaela (2016): Postoj polské rimskokatolické církve kotázce evropské integrace Polska. Brno: Bakalářské práce. Masarykova univerzita.

Šaradín, Pavel a Eva Bradová (2007): Visegrad voters: Parliamentary Elections 2005-2006. Olomouc: Palacký University.

Šulc, Jan (2011): Volebni geografie Polska po roce 1989. Praha: Diplomová práce. Univerzita Karlova.

Voda, Petr (2015): Jaká je role postkomunismu? volebni geografie Ceské a Rakouské republiky v letech 1990-2013. Brno: Centrum pro studium demokracie a kultury. Politologická rada.

Löwis, Sabine von (2015): „Phantom borders in the political geography of East Central Europe.“ Erdkunde 59(2): 99-106.

WESSA.NET (2017): Free Statistics and Forecasting Software: online (http://wessa.net/).

Zarycki, Tomasz (1997): Nowa przestrzenén spoleczno-polityczna Polski. Warszawa: EUROREG UW.

Zarycki, Tomasz (1999): The New Electoral Geography of Central Europe: online (http://193.0.101.165/zarycki/teczka/pdf/RSS2.pdf).

Zarycki, Tomasz (2015): „The electoral geography of Poland: between stable spatial structures and their changing interpretations." Erdkunde 69(2): 107-124. DOI: 10.3112/erdkunde.2015.02.02

\section{Poland A, B and C? Electoral Geography of Selected Voivodeships in Poland \\ SUMMARY}

Since 1989 it's possible to see a development in free political competition in Poland. One of the main components, party system, is from the beginning of $21^{\text {th }}$ century more stable than before and it's based on four political subjects - Law and Justice (PiS), Civic Platform (PO), Polish People's Party (PSL) and Democratic Left Alliance (SLD). These parties since elections in 2001 to nowadays hold majority seats in lower chamber (Sejm) of the Polish parliament.

Also, in the turn of the millennium a new administrative division of Poland was established and led to create 16 areas (voivodeships). These regions have a different past, when (since Partition of Poland in $18^{\text {th }}$ century until 1918 and 1945) they were parts in other countries - Prussia (later Germany), Austria and Russia. Between these territories we can see the differences not only in the electoral results, but in the cultural and society spheres as well (known as a Poland A vs. Poland B, sometimes Poland C). For this reason, one voivodeship from each of three areas (Lower Silesian, Lódź and Lesser Poland) with the most similarities in basic elements and socioeconomic statistic was 
picked and used as subjects for a spatial analyse of electoral support of four parties mentioned above.

Basic level of this analysis was a gminas, principal unit of Polish public administration. Main goal of study was a detection, if the development of the electoral support of parties in Sejm elections in this century shows similarities or differences and whether there are some connections among their electorates. Also important was a research about structure of voting support resources and consistence among various voting areas (parliamentary, presidential and EP elections during 2001-2015). Study used standard approaches in electoral geography - cartographical views on main electoral support bases, coefficient of variation and Gini coefficient, correlation coefficient and in several cases a linear regression analysis. Part of text is also dedicated to summary of literature about topic in Czech Republic and Poland, description of methods and mode of selection of voivodeships to research.

In general level on results, PiS and PO two right-wing subjects, are since 2005 main political powers in Poland, but in last elections conservative Law and Justice achieved a decisive victory against liberal Civic Platform. On the contrary, the leftist SLD after victory in 2001 with more than $40 \%$ support fell to $11 \%$ in 2005, and around this number stayed until 2015, when (in a coalition with another subjects) it was declined from Sejm. Agrarian PSL operated in whole period between 5-10\%. Situation in examined region was similar, but PO was in a long term strongest in Lower Silesian, while PiS had a leadership position in Lesser Poland. Situation in Lódź voivodeship wasn't clearly for one of parties.

Correlation analysis of electoral results shows dynamic process especially between PiS and PO - in first two elections was positive, since 2007 is turned into a strong negative, with means the electorate of these two parties is separate from each other and this trend is progressive after every election. In an overall situation, relationships among the electoral bases in all four parties are lowest in a Lower Silesia, i.e. area with complete population change after WWII. In other two regions, where Polish citizens were before war, is electorate more structured.

Analysis of individual political parties brought data's and significant statements about their voter's structure. Law and Justice can be described as a subject with the support in a smaller towns and villages, balanced distribution of voters and high stable supporter bases between diverse types of elections. These statements are valid more after 2007. For explanation of changes in party electorate before was chosen a regression analysis of relationship within PiS, LPR (League of Polish Families) and Self-Defence two radical right-wing subjects, which participated on PiS governments during 2005-2007. According to analysis it's possible to say that in this period Law and Justice particularly took their supporters (more from LPR) and acquired new voters.

Situation of the Civic Platform is different, this party has stable sources of electoral support since 2001. Core of it is in bigger cities and metropoles (Wrocław, Lódź and Kraków), this statement is confirmed also on values of variance and Gini coefficients, which showed a stronger concentration of voter's favour. With partial exception of Lesser Poland is results stable through years. Significant decrease of support during 2011 2015 (from 39,2\% to 24,1\%) could be from a relevant part caused (according on results of regression analysis) by success of M. (Modern), new centre-right oriented subject. 
Polish People's Party is highly oriented to rural areas and without relevant support in regional centres. For this reason, there is a distinct difference between values on methods focused on support uniformity and inequality (Variation and Gini coefficient). Because PSL is the party with long history and stable political position, it's no surprising that it's party support is without bigger changes in structure.

Last party, SLD, candidate in 2001, 2007 and 2015 as a main component of wide coalitions of left and centre-left subjects. It's a one of reasons that SLD shows the largest differences between voivodeships - in Łódź region is its support higher in a capital city, but in other two areas is stronger in parts with lower population. In terms of support concentration there is a same situation like with PSL, but extraordinary is stability measured by correlation coefficient - its values are relatively strong in whole period, although SLD passed a fundamental change of relevance during 2001-2015 and had various types of candidature (mentioned above).

As a conclusion: Due to picked regions with lots of similarities and diverse mostly from historical circumstances, it's possible to make some generalization about Polish voivodeships: Regions from Poland B (and possible say Poland C) on east and southeast is in a long term shows more stable and stronger structure of electoral results than Poland A zone in west. Main parties are in most of cases very consistent with their support basis, with exception of PiS during 2001-2007. And finally, two leading subjects and biggest rivals in party system, PiS and PO, has a supporter bases in different areas, but not only in state level, but also within individual regions. This "splitting of the country" between them in growing in every next election and confirmed a tense situation in contemporary Polish politics. 


\section{Př́lohy}

\section{Mapa 16: Dolnoslezské vojvodství dle gmin}

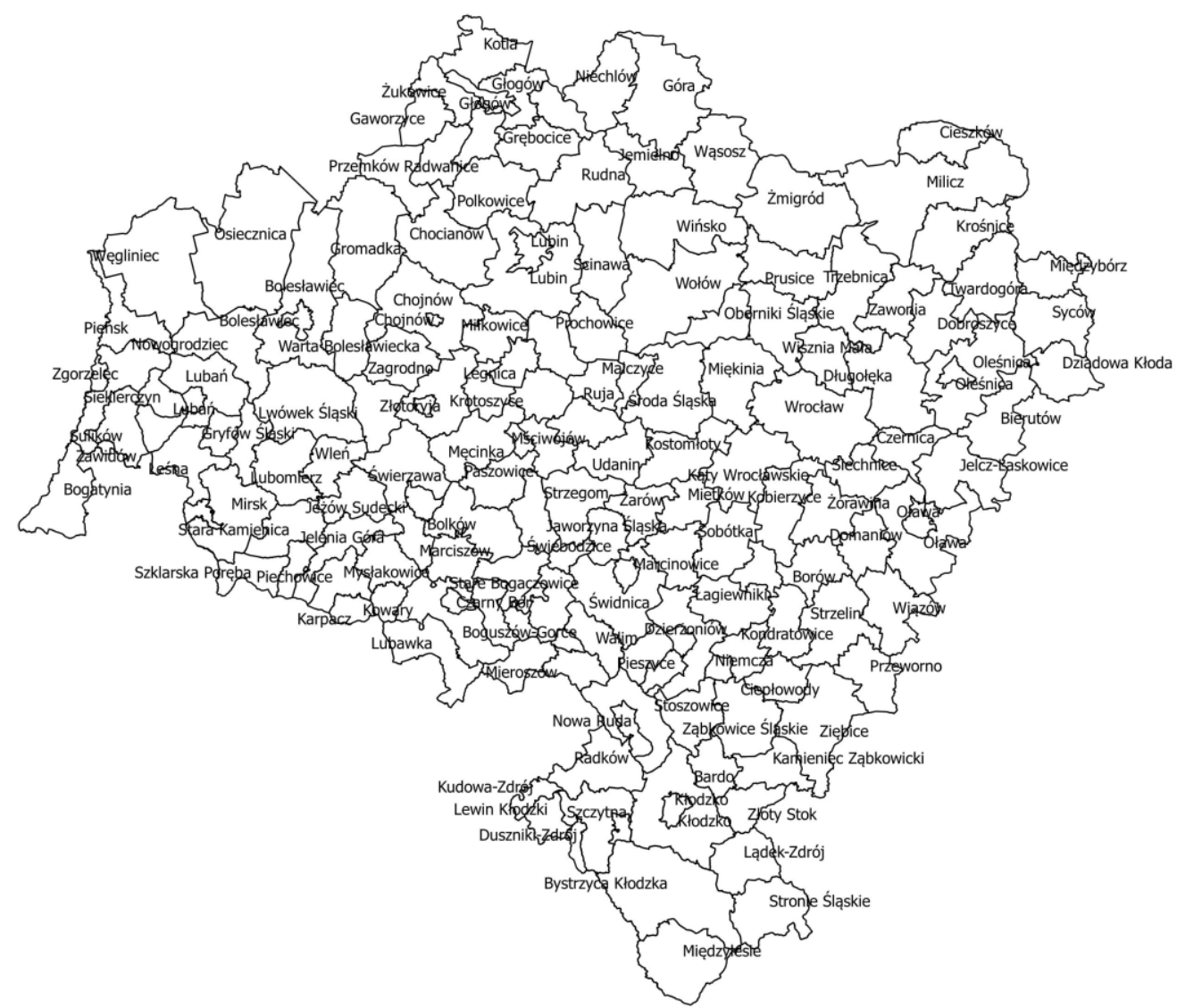

Zdroj: Vlastní mapa autora. 


\section{Mapa 17: Lodžské vojvodství dle gmin}

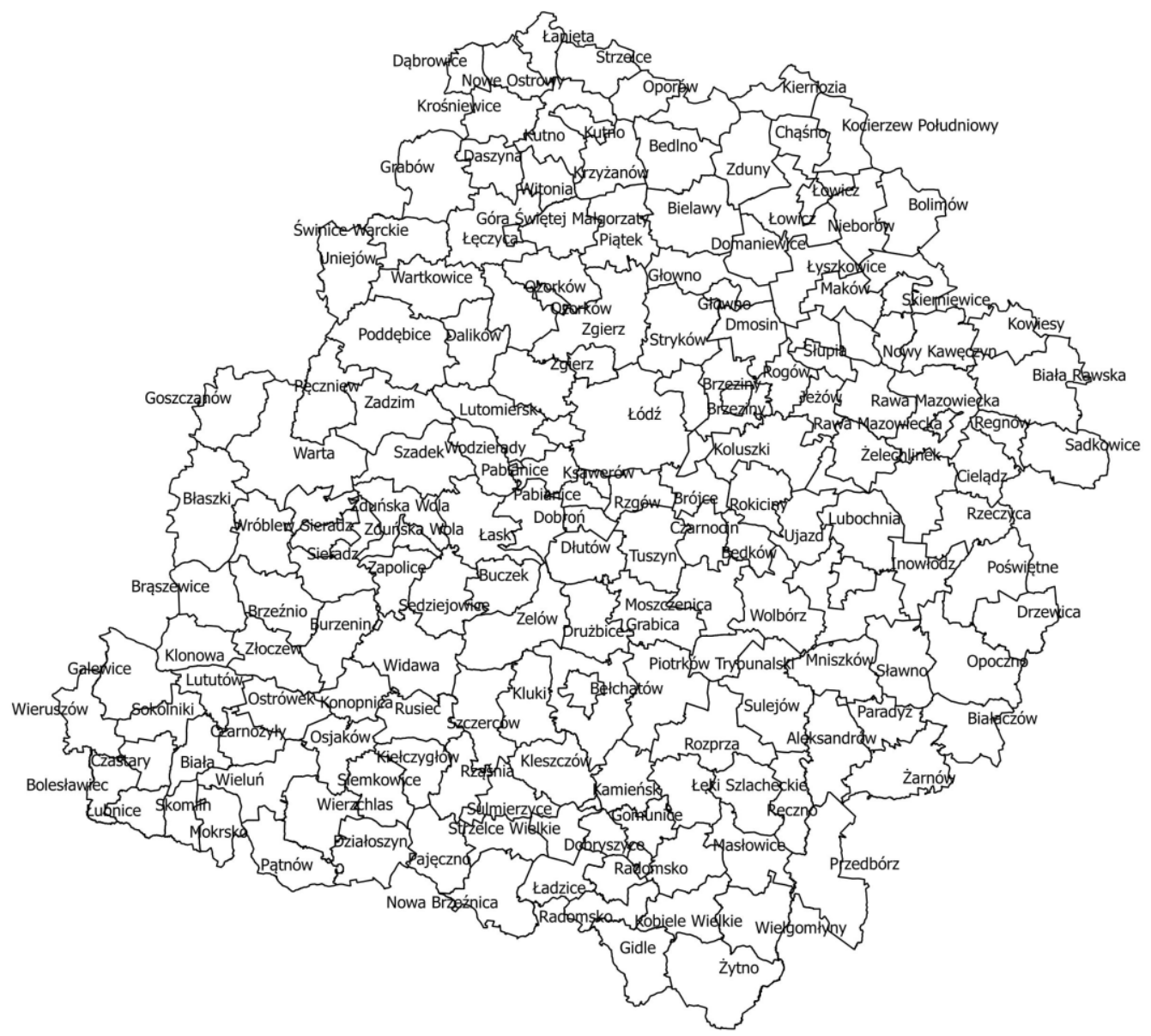

Zdroj: Vlastní mapa autora. 


\section{Mapa 18: Malopolské vojvodství dle gmin}

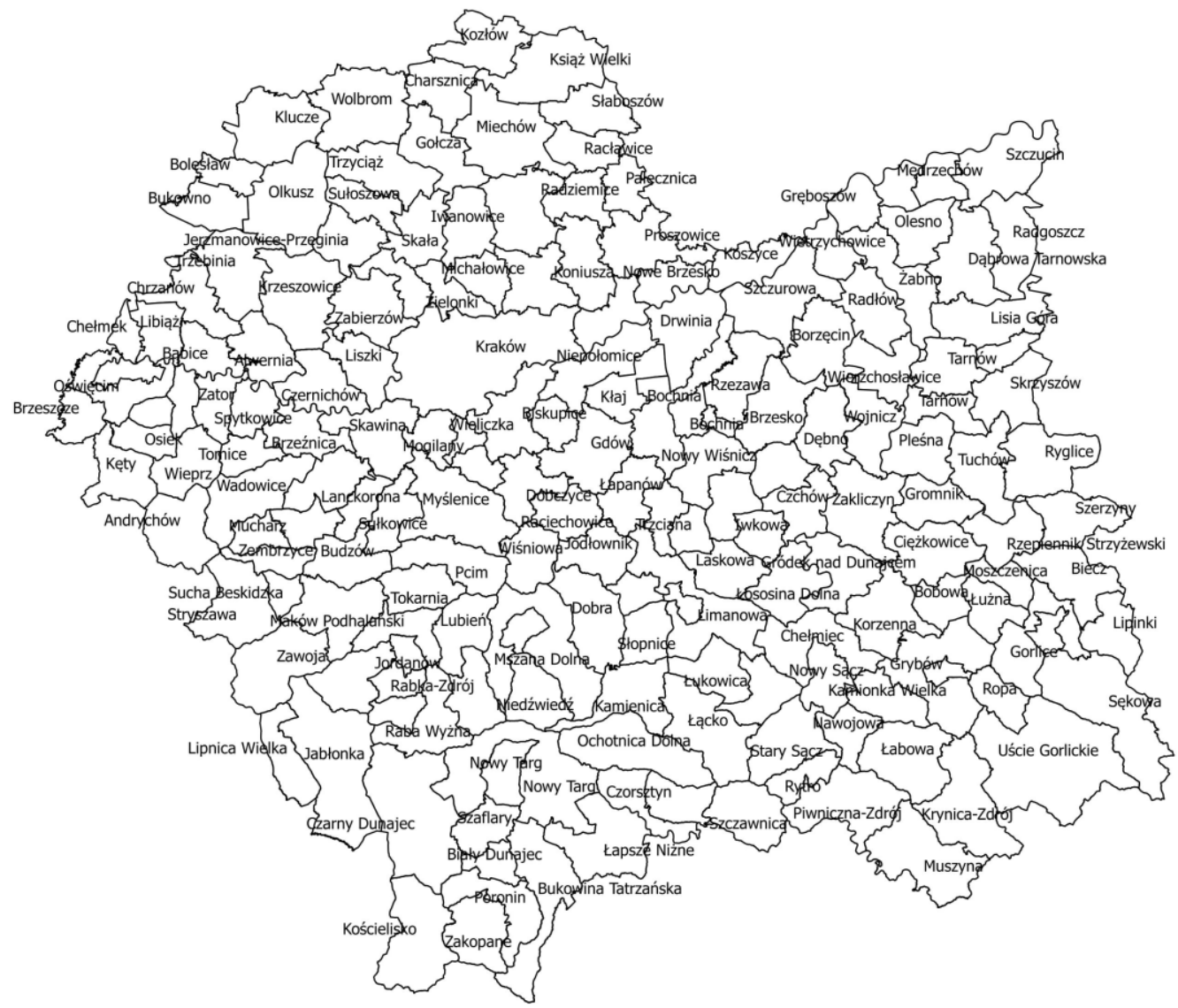

Zdroj: Vlastní mapa autora.

Tabulka 30: Výsledky zkoumaných stran ve volbách do Sejmu v letech 2001-2015

\begin{tabular}{|c|c|c|c|c|c|}
\hline Strana/volby & $\mathbf{2 0 0 1}$ & $\mathbf{2 0 0 5}$ & $\mathbf{2 0 0 7}$ & $\mathbf{2 0 1 1}$ & $\mathbf{2 0 1 5}$ \\
\hline PiS & $9,50 \%$ & $26,99 \%$ & $32,11 \%$ & $29,89 \%$ & $37,58 \%$ \\
\hline PO & $12,68 \%$ & $24,14 \%$ & $41,51 \%$ & $39,18 \%$ & $24,09 \%$ \\
\hline SLD & $41,04 \%$ & $11,31 \%$ & $13,15 \%$ & $8,24 \%$ & $7,55 \%$ \\
\hline PSL & $8,98 \%$ & $6,96 \%$ & $8,91 \%$ & $8,36 \%$ & $5,13 \%$ \\
\hline
\end{tabular}

Zdroj: Vlastní tabulka autora. 
Tabulka 31: Výsledky zkoumaných stran ve volbách do Sejmu v letech 2001-2015 v Dolnoslezském vojvodství

\begin{tabular}{|c|c|c|c|c|c|}
\hline Strana/volby & $\mathbf{2 0 0 1}$ & $\mathbf{2 0 0 5}$ & $\mathbf{2 0 0 7}$ & $\mathbf{2 0 1 1}$ & $\mathbf{2 0 1 5}$ \\
\hline PiS & $7,84 \%$ & $24,61 \%$ & $28,11 \%$ & $25,97 \%$ & $32,63 \%$ \\
\hline PO & $13,92 \%$ & $28,31 \%$ & $48,34 \%$ & $45,95 \%$ & $29,65 \%$ \\
\hline SLD & $47,25 \%$ & $12,59 \%$ & $14,03 \%$ & $8,70 \%$ & $8,05 \%$ \\
\hline PSL & $5,27 \%$ & $4,09 \%$ & $6,06 \%$ & $5,04 \%$ & $3,14 \%$ \\
\hline
\end{tabular}

Zdroj: Vlastní tabulka autora.

Tabulka 32: Výsledky zkoumaných stran ve volbách do Sejmu v letech 2001-2015 v Lodžském vojvodství

\begin{tabular}{|c|c|c|c|c|c|}
\hline Strana/volby & $\mathbf{2 0 0 1}$ & $\mathbf{2 0 0 5}$ & $\mathbf{2 0 0 7}$ & $\mathbf{2 0 1 1}$ & $\mathbf{2 0 1 5}$ \\
\hline PiS & $7,41 \%$ & $23,09 \%$ & $34,00 \%$ & $31,48 \%$ & $38,35 \%$ \\
\hline PO & $9,52 \%$ & $18,51 \%$ & $35,65 \%$ & $35,84 \%$ & $23,15 \%$ \\
\hline SLD & $44,75 \%$ & $13,57 \%$ & $15,02 \%$ & $9,24 \%$ & $8,79 \%$ \\
\hline PSL & $9,95 \%$ & $8,14 \%$ & $9,94 \%$ & $9,05 \%$ & $5,93 \%$ \\
\hline
\end{tabular}

Zdroj: Vlastní tabulka autora.

Tabulka 33: Výsledky zkoumaných stran ve volbách do Sejmu v letech 2001-2015 v Malopolském vojvodství

\begin{tabular}{|c|c|c|c|c|c|}
\hline Strana & $\mathbf{2 0 0 1}$ & $\mathbf{2 0 0 5}$ & $\mathbf{2 0 0 7}$ & $\mathbf{2 0 1 1}$ & $\mathbf{2 0 1 5}$ \\
\hline PiS & $12,63 \%$ & $36,13 \%$ & $41,38 \%$ & $39,33 \%$ & $48,18 \%$ \\
\hline PO & $16,70 \%$ & $24,90 \%$ & $38,32 \%$ & $36,26 \%$ & $19,43 \%$ \\
\hline SLD & $29,99 \%$ & $7,21 \%$ & $8,70 \%$ & $5,42 \%$ & $4,73 \%$ \\
\hline PSL & $9,68 \%$ & $6,05 \%$ & $7,80 \%$ & $6,38 \%$ & $4,19 \%$ \\
\hline
\end{tabular}

Zdroj: Vlastní tabulka autora.

Tabulka 34: Volební účast ve zkoumaných vojvodstvích a Polsku ve volbách do Sejmu v letech 2001-2015

\begin{tabular}{|c|c|c|c|c|c|}
\hline Vojvodství & $\mathbf{2 0 0 1}$ & $\mathbf{2 0 0 5}$ & $\mathbf{2 0 0 7}$ & $\mathbf{2 0 1 1}$ & $\mathbf{2 0 1 5}$ \\
\hline Dolnoslezsko & $44,85 \%$ & $38,49 \%$ & $53,52 \%$ & $47,69 \%$ & $49,42 \%$ \\
\hline Lodžsko & $46,67 \%$ & $40,24 \%$ & $53,91 \%$ & $49,07 \%$ & $51,63 \%$ \\
\hline Malopolsko & $48,54 \%$ & $44,76 \%$ & $55,99 \%$ & $51,19 \%$ & $54,90 \%$ \\
\hline Polsko & $46,18 \%$ & $40,51 \%$ & $53,82 \%$ & $48,92 \%$ & $50,92 \%$ \\
\hline
\end{tabular}

Zdroj: Vlastní tabulka autora. 